NBER WORKING PAPER SERIES

\title{
FARM PRODUCT PRICES, REDISTRIBUTION, AND THE EARLY U.S. GREAT DEPRESSION
}

Joshua K. Hausman

Paul W. Rhode

Johannes F. Wieland

Working Paper 28055

http://www.nber.org/papers/w28055

\author{
NATIONAL BUREAU OF ECONOMIC RESEARCH \\ 1050 Massachusetts Avenue \\ Cambridge, MA 02138 \\ November 2020
}

Jon Denton-Schneider provided superb research assistance. We are grateful for comments and encouragement from Price Fishback, John Leahy, Gary Richardson, Christina Romer, Matthew Shapiro, Peter Temin, and audiences at the Society for Economic Dynamics, the University of Michigan, the NBER Development of the American Economy program meeting, and Florida State. Rhode's work was in part funded by NSF grant SES- 0921732 ("Dramatic Rise in Agricultural Productivity in the U.S During the Twentieth Century: Disentangling the Roles of Technological Change, Government Policy, and Climate"). The views expressed herein are those of the authors and do not necessarily reflect the views of the National Bureau of Economic Research.

NBER working papers are circulated for discussion and comment purposes. They have not been peer-reviewed or been subject to the review by the NBER Board of Directors that accompanies official NBER publications.

(C) 2020 by Joshua K. Hausman, Paul W. Rhode, and Johannes F. Wieland. All rights reserved. Short sections of text, not to exceed two paragraphs, may be quoted without explicit permission provided that full credit, including $(\odot$ notice, is given to the source. 
Farm Product Prices, Redistribution, and the Early U.S. Great Depression

Joshua K. Hausman, Paul W. Rhode, and Johannes F. Wieland

NBER Working Paper No. 28055

November 2020

JEL No. E32,E65,N12,N52,Q11,Q12

\section{ABSTRACT}

We argue that falling farm product prices, incomes, and spending may explain 10-30 percent of the 1930 U.S. output decline. Crop prices collapsed, reducing farmers' incomes. And across U.S. states and Ohio counties, auto sales fell most in crop-growing areas. The large spending response may be explained by farmers' indebtedness. Reasonable assumptions about the marginal propensity to spend of farmers relative to nonfarmers and the pass-through of farm prices to retail prices imply that the collapse of farm product prices in 1930 was a powerful propagation mechanism worsening the Depression.

Joshua K. Hausman

Gerald R. Ford School of Public Policy University of Michigan

735 South State Street, \#3309

Ann Arbor, MI 48109

and NBER

hausmanj@umich.edu

Paul W. Rhode

Economics Department

University of Michigan

205 Lorch Hall

611 Tappan St.

Ann Arbor, MI 48109-1220

and NBER

pwrhode@umich.edu
Johannes F. Wieland

Department of Economics

University of California, San Diego

9500 Gilman Drive \#0508

La Jolla, CA 92093

and NBER

jfwieland@ucsd.edu 
"The evils of deflation and liquidation through bankruptcy and default manifest themselves more malevolently in agriculture than in any other great industrial group." -Irving Fisher (Fisher, 1932, p. 32).

\section{Introduction}

The first year of the Great Depression in the United States was exceptionally severe, much more severe than that in other countries. Figure 1 shows the path of U.S. industrial production in the first year of the Great Depression. Had the U.S. Depression ended in 1930, the output decline would still have been more severe than that in any other post-1869 recession with the exception of 1945-46 and, perhaps, 2020. ${ }^{1}$ Industrial production fell 27 percent from its peak in July 1929 to October 1930; year-on-year, in 1930, real GDP fell 8.5 percent. $^{2}$ In her sample of 23 countries, Romer (1993, table 1) finds that the U.S. was the only country in 1930 to see a year-over-year decline in industrial production of over 20 percent; among the 15 countries in which industrial production fell, the median decline was 9 percent (Romer, 1993, p. 21).

We argue that the size and characteristics of the agricultural sector explain part of why initial negative shocks resulted in a large downturn. This helps to account for why 1930 was an exceptionally bad year for the U.S. economy despite continued stability of the banking system through most of the year. The worldwide recession that began in summer 1929 quickly lowered the prices of farm products, particularly those of internationally traded crops. These price declines in turn depressed farmers' incomes. Likely because lower farm incomes interacted with fixed nominal debt burdens, spending in agricultural areas collapsed. We estimate that absent this propagation through the agricultural sector, the output decline in the first year of the Depression would have been at least 10 to 30 percent smaller.

To document the importance of farmers for the severity of the early U.S. Great Depression, we proceed in four steps. First, in the next section, we show that at the beginning of the Depression, farm product prices fell rapidly in both absolute and relative terms, depressing farm incomes. These price declines were particularly large for crops exposed to world

\footnotetext{
${ }^{1}$ This statement is based on a comparison with real GNP data from Romer (1989) for 1869-1928 and with data from NIPA table 1.1.1 thereafter.

${ }^{2}$ Seasonally adjusted industrial production data are from FRED series INDPRO; GDP data are from NIPA table 1.1.1.
} 
Figure 1 - Industrial production

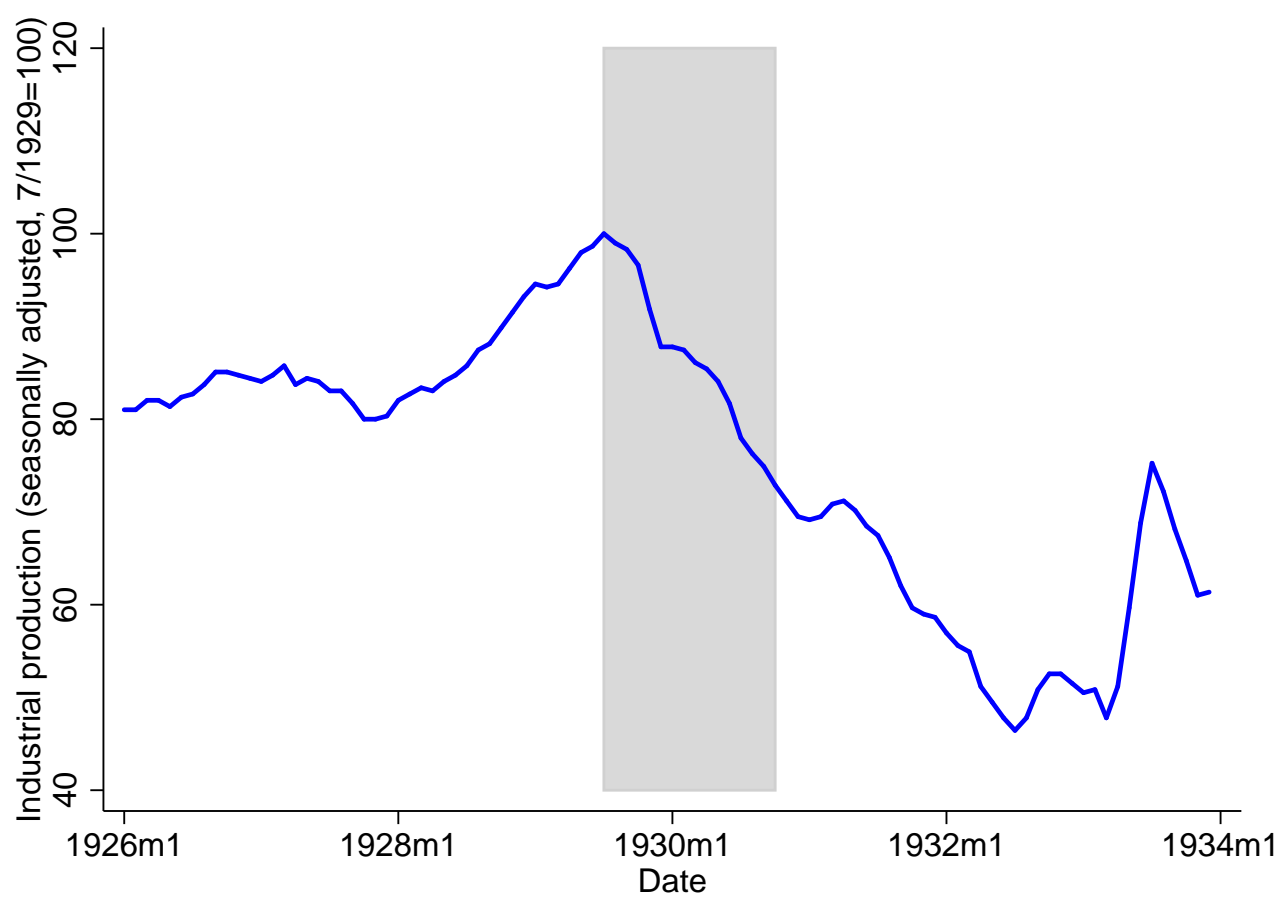

Note: Shading indicates July 1929 to October 1930, the period of the Great Depression before the first banking panic. Source: FRED series INDPRO.

demand. Entirely because of price declines, the combined dollar value of U.S. cotton, wheat, and tobacco production fell 38 percent between 1929 and $1930 .^{3}$

In section 3, we show that in 1930 the spending of farmers fell relative to nonfarmers. To examine farm spending, we use monthly auto sales data by state and newly-collected data on auto sales in Ohio counties. ${ }^{4}$ We find that in the first year of the Depression, spending fell more in states and counties most exposed to falling crop prices. The cross-sectional effect of exposure to farm product price declines is large: a one standard deviation increase in the share of a state's population living on farms is associated with a 5.5 percentage point larger decline in auto sales between the second and third quarter of 1929 and the second and third quarter of 1930. Qualitatively similar results in some (though not all) specifications in the county and state data increase our confidence in the economic significance of the relationship between farming and the Depression. The similarity of the results across Ohio counties and

\footnotetext{
${ }^{3}$ Data on the dollar value and physical volume of production come from United States Department of Agriculture (1936). Data on wheat come from table 1, p. 6; cotton - table 98, p. 76; tobacco - table 143, p. 104.

${ }^{4}$ We use "auto" and "car" interchangeably.
} 
across all U.S. states suggests that this relationship is not simply an idiosyncratic artifact of a few states' performance.

A large cross-sectional effect of exposure to farm product prices need not indicate an important role for farmers in the aggregate. But redistribution away from farmers would have mattered for the aggregate economy if farmers had higher marginal propensities to consume (MPCs) than the companies and workers benefiting from lower farm product prices. ${ }^{5}$ In section 4, we show that this is plausible because farmers entered the Great Depression with high nominal debt burdens, and because there was incomplete pass-through of lower farm product prices to lower consumer prices.

In the final section of the paper, section 5, we use the structure of the model in Hausman, Rhode, and Wieland (2019) to obtain a quantitative sense of the effect of falling farm product prices on the severity of the early Great Depression. We ask: if relative farm product prices had not declined before November 1930, how much less severe would the first year of the Depression have been? We find that lower farm product prices likely explain at least 1030 percent of the output decline that occurred before fall 1930. The large range is due to uncertainty about the relative MPC of farmers and nonfarmers, the pass-through of farm product prices to final goods prices, and the aggregate multiplier.

This paper relates to several themes in the economic history and macroeconomics literatures. Most obviously, we contribute to the literature on the beginning of the Great Depression. Friedman and Schwartz (1963) (pp. 306-307) emphasize tight monetary policy as a cause of the initial output decline in 1930. But as noted by Temin (1976) and Romer (1993), the argument that monetary policy drove the initial downturn is problematic; over the fifteen months from July 1929 to October 1930, the real money supply grew 3.2 percent, ${ }^{6}$ and nominal interest rates fell. ${ }^{7}$ The literature points to the stock market crash (Romer,

\footnotetext{
${ }^{5}$ Here and throughout we abuse terminology and use "marginal propensity to consume (MPC)" to refer to all spending by farmers, not just spending on consumption goods. From the perspective of the aggregate economy in the short-run, it was equally contractionary for a farmer to forgo a purchase of a car for investment purposes as it was for a farmer to forgo a purchase of a car for consumption purposes. In practice, it seems likely that farmers often purchased a car with the expectation that it would be used for both consumption and business purposes; surveys conducted in 1935-36 suggest that roughly one-third to one-half of farmers' car use was for business purposes (United States Department of Agriculture, 1940, p. 34, table 15).

${ }^{6}$ This refers to the seasonally adjusted broad nominal money supply (from Friedman and Schwartz (1963), table A-1, column 9, pp. 712-713) deflated by the CPI (FRED series CPIAUCNS).

${ }^{7}$ The 4-6 month prime commercial paper rate fell from 6 percent in July 1929 to 3 percent in October
} 
1990) and consumer debt burdens (Olney, 1999) as causes of the large decline in U.S. output before the first banking crisis. And in a recent paper, Gorton, Laarits, and Muir (2019) argue that despite the lack of depositor runs, bank behaviour contributed to the output decline in 1930, as banks cut back on loans in favor of safe assets. Since the upper end of our range for the effect of lower farm product prices on 1930 output still leaves two-thirds of that year's output decline to be explained, our work is consistent with a large role for these other shocks and propagation mechanisms identified by prior authors. We add to this prior work by documenting substantial regional heterogeneity in the severity of the early Great Depression and by arguing that lower farm product prices, income, and spending are a plausible propagation mechanism through which exogenous shocks (e.g. the stock market crash) led to a large output decline.

Relative to the literature on the U.S. Great Depression, the literature on the international Great Depression has put more emphasis on agriculture. ${ }^{8}$ Kindleberger (1973) is concerned with how trade in agricultural products helped to transmit economic distress across countries. He devotes a chapter to "The Agricultural Depression," and he suggests that low farm product prices could have contributed to the Depression. He refers to the "conventional wisdom that price declines are deflationary in so far as they 'check confidence, provoke bank failures, encourage hoarding and in various ways discourage investment"' (Kindleberger, 1973, p. 142). Interestingly, however, he doubts the importance of the effect that we emphasize of a higher MPC among farmers translating lower farm product prices into lower aggregate spending (p. 142).

The more recent literature on agriculture and the international Great Depression is small. Most related to our work are Madsen (2001) and Federico (2005). Madsen (2001) examines

1930 (Board of Governors of the Federal Reserve System (1943), table 120, pp. 450-451). Hamilton (1992) shows that inflation expectations likely did not turn sharply negative until the last trimester of 1930; thus over the first year of the Great Depression, ex ante real interest rates were also probably falling.

${ }^{8}$ Earlier work by the agricultural economists George Warren and Frank Pearson (Warren and Pearson, 1935) does discuss negative effects of lower commodity prices on U.S. agriculture. And Temin (1976) (p. 146-151) briefly considers whether developments in the agricultural sector might have contributed to the U.S. downturn in 1930. Based on his reading of Kindleberger (1973), Temin concludes (p. 150) that "The fall in farm income may have played a disproportionate role in the fall in consumption in 1930 but the farm sector was too small by 1930 for changes within this sector to dominate the whole economy." Temin sees less of an aggregate role for farmers than we do, perhaps because he did not have the cross-sectional quantitative evidence we provide of a large relationship between agricultural intensity in a state and the size of the 1930 contraction in the state. 
the role of agricultural in transmitting the Great Depression across countries. Like us, he emphasizes that farmers probably had a higher MPC than nonfarmers. Using cross-country data, he concludes that falling agricultural prices likely account for a significant portion of the output decline during the Great Depression. Federico (2005) addresses a similar question but comes to a different conclusion. He is interested in whether conditions in agriculture substantially contributed to the severity of the Great Depression. He concludes that they did not. His evidence comes from (1) an analysis of world farm product demand and supply which suggests little overproduction in the 1920s, and (2) a review of the literature which finds limited support for the view that problems in agricultural areas were an independent cause of the nationwide banking panics in the U.S. Great Depression. Relative to Madsen (2001) and Federico (2005), we are focused more narrowly on one country (the U.S.) and one year (1929-1930). This allows us to look at detailed state and county data.

In addition to our findings' importance for understanding the aggregate U.S. economy at the beginning of the Depression, we also contribute to the literature on regional heterogeneity in the Depression's severity. We add to the findings in Garrett and Wheelock (2006), Rosenbloom and Sundstrom (1999), and Wallis (1989) in two ways. First, we quantify the large role of agriculture in explaining variations in state economic performance at the beginning of the Depression. Second, we show that it was internationally traded crop production rather than agricultural activity as a whole that drove differences in state performance.

We also contribute to a growing literature in macroeconomics on redistribution and MPC heterogeneity. Recent work in macroeconomics has stressed the importance of redistribution and MPC heterogeneity for aggregate outcomes. ${ }^{9}$ We show that these forces are also relevant to understanding the Great Depression.

\section{Farm prices and income}

Figure 2 plots the behaviour of an index of farm product prices and, for comparison, the producer price index and the CPI. It shows the extraordinary decline of farm product prices

\footnotetext{
${ }^{9}$ See, among others, Auclert (2019); Broer, Hansen, Krusell, and Öberg (2020); Cloyne, Ferreira, and Surico (2020); Kaplan, Moll, and Violante (2018); Krueger, Mitman, and Perri (2016); McKay, Nakamura, and Steinsson (2016); Patterson (2019); Werning (2011).
} 
Figure 2 - Prices

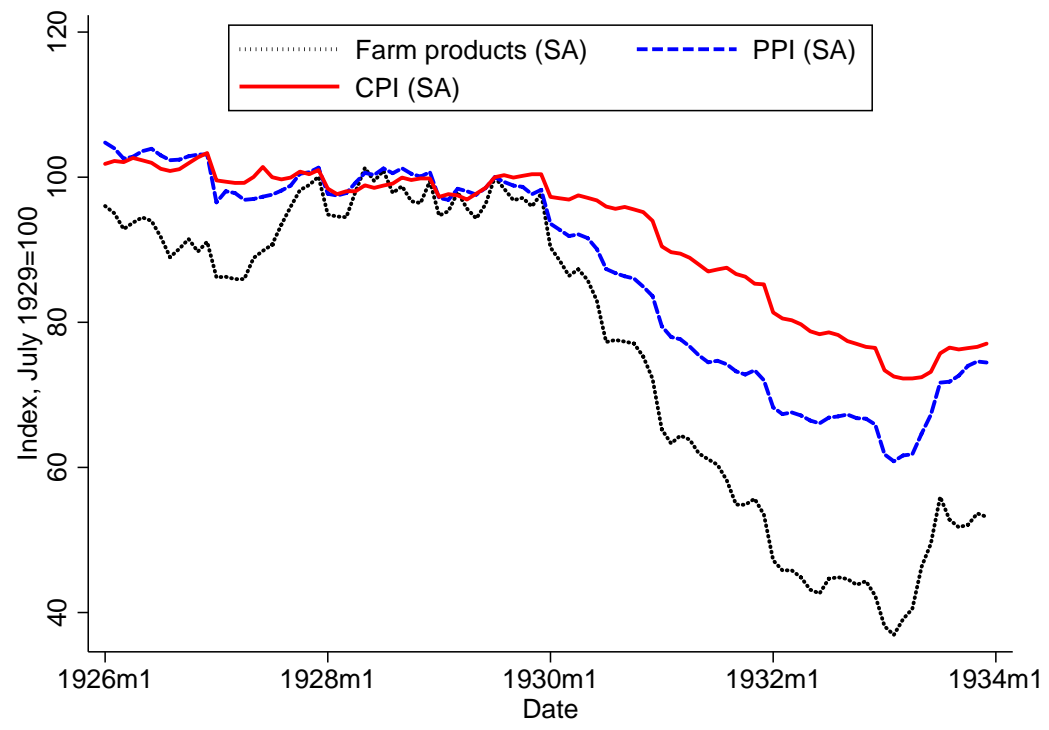

Note: The figure shows the level of seasonally adjusted farm product prices, producer prices (PPI) and consumer prices (CPI). Sources: Farm product prices: FRED series M04058USM350NNBR, originally from NBER series m04058 which was collected from BLS publications; PPI: FRED series PPIACO; CPI: FRED series CPIAUCNS. We seasonally adjust these series using data from 1926 through 1935, excluding 1933 because of the very large farm product price movements in that spring. Seasonally adjusted prices in month $t$ are $e^{\hat{\varepsilon}_{t}+\sum_{j=1}^{12} \hat{\beta}_{j} / 12}$, where $\hat{\varepsilon}_{t}$ is the residual from a regression of the price index on monthly dummies, and $\hat{\beta}_{j}$ is the OLS coefficient on the month $j$ dummy

in absolute and relative terms after the summer 1929 business cycle peak. Figure 2 shows that rapid farm product price declines began only in early 1930. Industrial production peaked in July 1929 and fell rapidly after October (Figure 1); therefore, this timing strongly suggests that lower farm product prices were not an exogenous shock causing the U.S. Depression; they were a response to the Depression and, we shall argue, a propagation mechanism worsening the Depression.

The prices of all major farm products fell in 1930, but the price decline was not uniform. Table 1 shows the prices of 12 major farm products early in the Depression. In 1930, the prices of wheat, cotton, and tobacco fell more than those of other crops. This is consistent with a possible contribution of recession abroad to the price decline: cotton, tobacco, and wheat are the three crops in Table 1 that were traded most internationally. Figure 3 illustrates the large divergence in the paths of traded and nontraded farm product prices after the beginning of the Depression. Of course, recession abroad may itself have been caused by recession in the U.S. So it is difficult to quantify the extent to which traded crop price declines were an endogenous response to the U.S. recession. Large declines in the prices of 
Table 1 - Farm product prices

Panel A: Crops

\begin{tabular}{|c|c|c|c|c|c|c|c|}
\hline & Wheat & Corn & Oats & Cotton & Tobacco & Hay & Potatoes \\
\hline \multicolumn{8}{|l|}{ Prices $(\mathrm{SA}$, Index, 1928=100) } \\
\hline 1929 Q2 & 80 & 96 & 84 & 96 & & 110 & 71 \\
\hline 1929 Q3 & 98 & 98 & 97 & 93 & & 107 & 138 \\
\hline $1929 \mathrm{Q} 4$ & 98 & 104 & 99 & 94 & & 108 & 186 \\
\hline $1930 \mathrm{Q} 1$ & 85 & 88 & 80 & 79 & & 100 & 165 \\
\hline $1930 \mathrm{Q} 2$ & 78 & 86 & 78 & 77 & & 99 & 177 \\
\hline 1930 Q3 & 65 & 89 & 78 & 57 & & 110 & 131 \\
\hline $1930 \mathrm{Q} 4$ & 57 & 88 & 74 & 52 & & 116 & 130 \\
\hline 1928, average & 100 & 100 & 100 & 100 & 100 & 100 & 100 \\
\hline 1929 , average & 91 & 99 & 92 & 95 & 103 & 109 & 116 \\
\hline 1930 , average & 71 & 88 & 78 & 66 & 79 & 106 & 151 \\
\hline \multicolumn{8}{|l|}{ Production } \\
\hline 1929 farm product value ( $\$$, millions $)$ & 852 & 2024 & 468 & 1245 & 282 & 1018 & 431 \\
\hline $1929-30$ change in quantity $(\%)$ & 8 & -19 & 14 & -6 & 7 & -15 & 2 \\
\hline 1929, trade output share, $(\mathrm{X}+\mathrm{M}) / \mathrm{Y}(\%)$ & 20 & 0 & 1 & 50 & 43 & 0 & 3 \\
\hline
\end{tabular}

Panel B: Animal products

\begin{tabular}{|c|c|c|c|c|c|}
\hline & Cattle & Hogs & Milk & Chickens & Eggs \\
\hline \multicolumn{6}{|l|}{ Prices $(\mathrm{SA}$, Index, 1928=100) } \\
\hline 1929 Q2 & 102 & 117 & 101 & 109 & 106 \\
\hline 1929 Q3 & 104 & 107 & 101 & 107 & 108 \\
\hline $1929 \mathrm{Q} 4$ & 98 & 105 & 100 & 101 & 104 \\
\hline $1930 \mathrm{Q} 1$ & 95 & 107 & 91 & 96 & 102 \\
\hline $1930 \mathrm{Q} 2$ & 89 & 107 & 91 & 90 & 86 \\
\hline $1930 \mathrm{Q} 3$ & 72 & 93 & 89 & 82 & 77 \\
\hline $1930 \mathrm{Q} 4$ & 73 & 98 & 88 & 81 & 69 \\
\hline 1928 , average & 100 & 100 & 100 & 100 & 100 \\
\hline 1929, average & 101 & 108 & 100 & 106 & 106 \\
\hline 1930 , average & 82 & 101 & 90 & 87 & 84 \\
\hline \multicolumn{6}{|l|}{ Production } \\
\hline 1929 farm product value ( $\$$, millions $)$ & 962 & 1,482 & 3,021 & 524 & 794 \\
\hline $1929-30$ change in quantity $(\%)$ & 0 & -6 & 1 & -3 & 4 \\
\hline 1929, trade output share, $(\mathrm{X}+\mathrm{M}) / \mathrm{Y}(\%)$ & 2 & 7 & $\mathrm{~N} / \mathrm{A}$ & $\mathrm{N} / \mathrm{A}$ & 2 \\
\hline
\end{tabular}

Notes and sources: Prices are producer prices (prices received by farmers); annual prices are unweighted calendar year averages. Farm product value equals physical production times price. Farm product value and production figures are for the crop year, which is not necessarily the calendar year. For further notes and source details, see the appendix. 
mostly nontraded animal products (panel B) suggest that international factors were not the only driver of farm product price declines.

Figure 3 - Traded and nontraded farm product prices

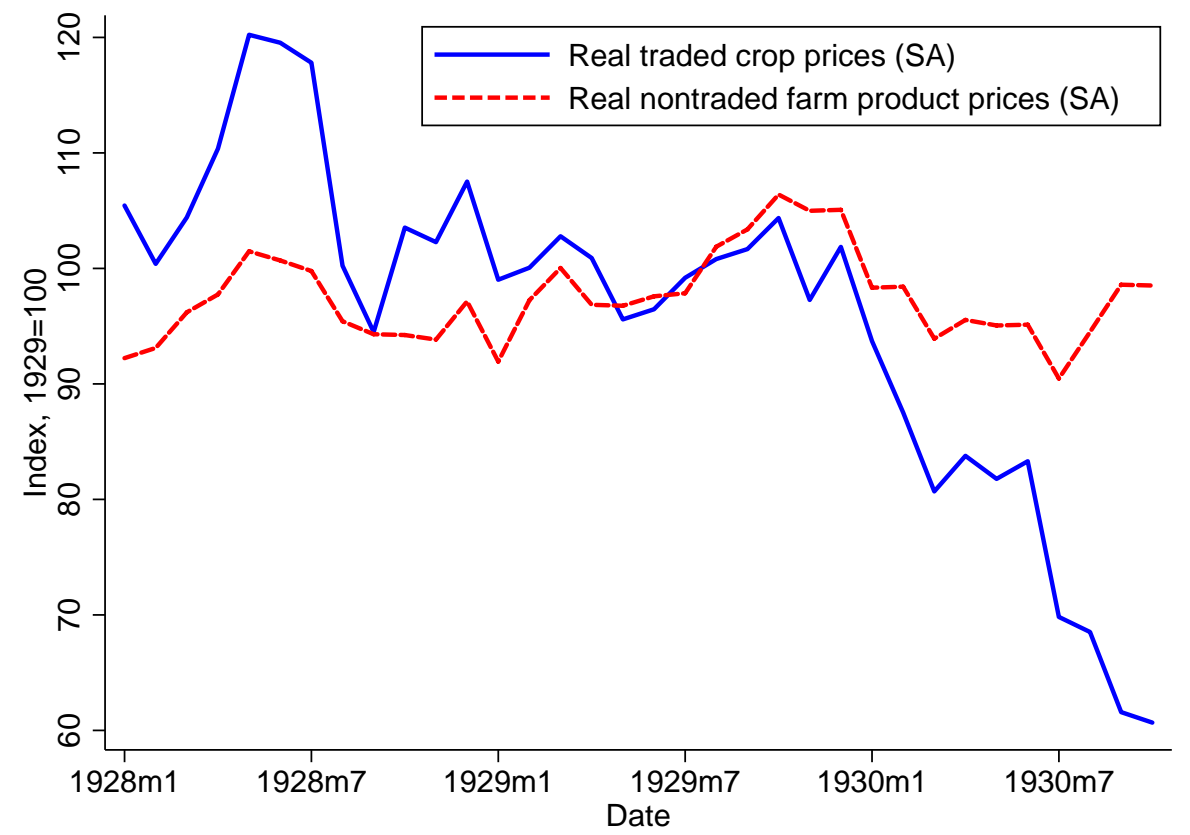

Notes: The figure shows seasonally adjusted traded crop and nontraded farm product prices. Traded crops are wheat, cotton, and wool, major internationally traded crops for which monthly price data are available. Tobacco is excluded because only annual prices are available. Nontraded farm products are corn, potatoes, hay, cattle, hogs, milk, eggs, and chickens; these products were traded little internationally. See appendix B for details on the sources and construction of these price indices.

The large farm product price decline is likely explained by a decrease in demand (foreign and domestic) combined with the near total inelasticity of supply of farm products. Demand fell as the U.S. and foreign economies fell into recession. In the short-term, supply was determined by past planting decisions. And even in the medium-term, farmers facing price declines for their products may have maintained production; a price decline for a farmer has a substitution effect pushing a farmer to plant less but an income effect pushing a farmer to plant more. These forces were combined with an influx of workers into agriculture during the Great Depression, as unemployed urban workers moved to rural areas. Throughout the 1920s, there was net migration from farm to cities; this pattern reversed in 1930 with net migration to farms from cities each year from 1930-33 (United States Department of Agriculture, 1936, table 445, p. 339). Ezekiel and Bean (1933) (p. 21) argue that "Left to themselves, farmers as a group have been unable to readjust their total production in line 
with the reduced demands." ${ }^{10}$ An inelastic supply of farm products was of course not unique to the Great Depression. Bordo (1980) notes that at least since Cairnes (1873) economists have known that inelastic supply may make commodity prices more volatile than the prices of manufactured goods. ${ }^{11}$

The effect of large commodity price movements depends on their incidence; it was the U.S. economy's misfortune in 1930 that the burden of lower farm product prices fell on indebted farm households. An individual farmer's income roughly equaled the price of their product times the quantity produced, so the large decline in farm product prices produced a large decline in farmers' incomes. This is a key difference between farm products and other commodities; when the price of, say, iron ore falls the immediate effect is to lower the profits of iron mining firms; the incomes of mining households only fall when wages for iron miners decline, a process likely to take months if not years. Changes in farm product prices, by contrast, have a direct, rapid impact on the incomes of farm households.

Farm incomes are shown in Figure 4. Between July 1929 and October 1930, real, cpideflated farm income fell 29 percent; income from crops fell 42 percent. While individuals who became unemployed may have seen larger income declines, the decline in income for the typical farmer was far larger than that for the typical nonfarm worker. Annual data from the BEA (table SA04) show that CPI-deflated nonfarm personal income fell 6.3 percent between 1929-1930; over the same period, CPI-deflated farm income fell 25.1 percent.

To understand whether the fall in farm income in 1930 was driven by lower farm product prices, Figure 5 shows farm income and the quantity of marketed farm products from 1927 to 1930. Unlike the series shown in Figure 4, these series are not seasonally adjusted; thus they show the regular seasonal peak in fall of farm products sold and farm income received. Income and marketing track each other closely until mid-1930, when farm marketing rises in its typical seasonal fashion, while farm income increases little relative to its normal seasonal increase. The unusually small increase in farm income reflects falling farm product prices. The behaviour of these series shows that before mid-1930 falling seasonally adjusted farm

\footnotetext{
${ }^{10}$ This is the heading of a subsection that goes on to describe the movement of city workers to farms and the fact that bankruptcy did not typically stop production on a farm (Ezekiel and Bean, 1933, p. 21).

${ }^{11}$ Bordo (1980) adds to this argument by showing that commodity price flexibility also makes commodity (including agricultural) prices more volatile in response to monetary shocks.
} 
Figure 4 - Farm income

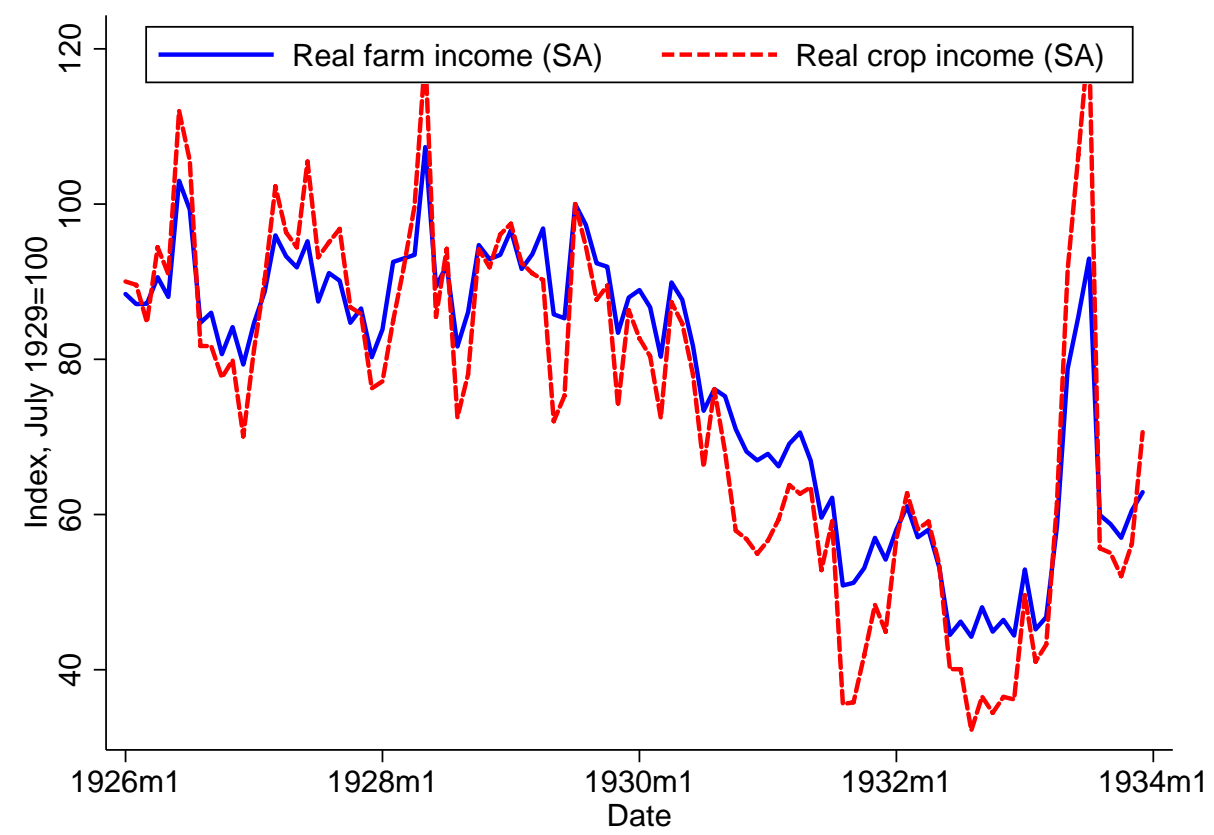

Note: The figure shows seasonally adjusted total farm income and income from crop production. Sources: Pre-1932- Survey of Current Business, May 1934, p. 19. 1932-33: 1936 Supplement - Survey of Current Business, p. 9. These nominal values are deflated by the CPI (not seasonally adjusted), taken from FRED series CPIAUCNS.

incomes (Figure 4) may have largely reflected less marketing of farm products. Reduced marketing may have been a result of drought which shrank the 1929 harvest. (In our crossstate regression below, we control for drought conditions.) In any case, beginning in summer 1930 lower farm product prices are the clear driver of lower farm incomes. 
Figure 5 - Farm income and marketing

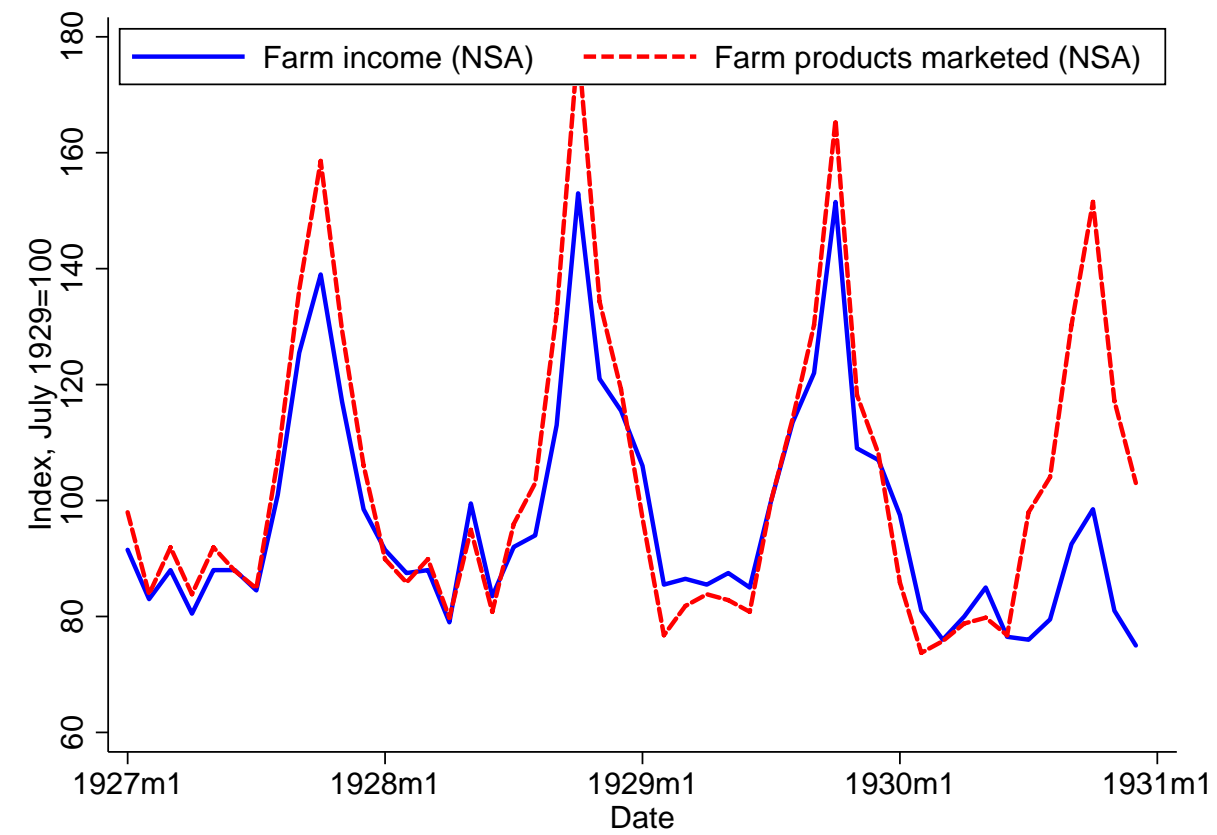

Note: The figure shows nominal farm income and the quantity of farm products marketed. Neither series is seasonally adjusted. Sources: Farm income - Survey of Current Business, May 1934, p. 19. Farm marketing - Survey of Current Business, March 1933, p. 20.

\section{Expenditure in farm areas}

The large decline in farm product prices and incomes led to a collapse of spending in farm areas. Initial evidence for this comes from a comparison of rural and small town retail sales with department and variety store sales. Rural and small town retail sales are a Department of Commerce index (U.S. Department of Commerce, 1934a) that uses data on mail order and chain store sales to measure consumption in small towns (those with population less than 10,000) and on farms. ${ }^{12}$ Department stores were located in urban areas and thus capture a part of urban consumption. They have the disadvantage, however, of being weighted towards higher-price goods. The U.S. Department of Commerce (1934c) developed an index of variety store sales in part to correct for this bias. The variety store index has the disadvantage for our purpose, however, of being based on a sample that puts a heavy weight on relatively small cities, those with population less than 100,000. Still, the Department of Commerce

\footnotetext{
${ }^{12}$ The underlying data for this index were provided by Chicago Mail Order House, Montgomery Ward \& Co., Sears, Roebuck \& Co., and J. C. Penney Co. For further details, see U.S. Department of Commerce (1934a).
} 
saw this series as at least somewhat representative of consumption in urban areas (U.S. Department of Commerce, 1934a).

Figure 6 graphs these series between 1929 and 1933. (The rural and variety store indices begin in January 1929.) The indices start to diverge in December 1929; between July 1929 and October 1930, seasonally adjusted department store and variety store sales fell 7 percent; rural and small town retail sales fell 28 percent.

Figure 6 - Rural and urban retail sales

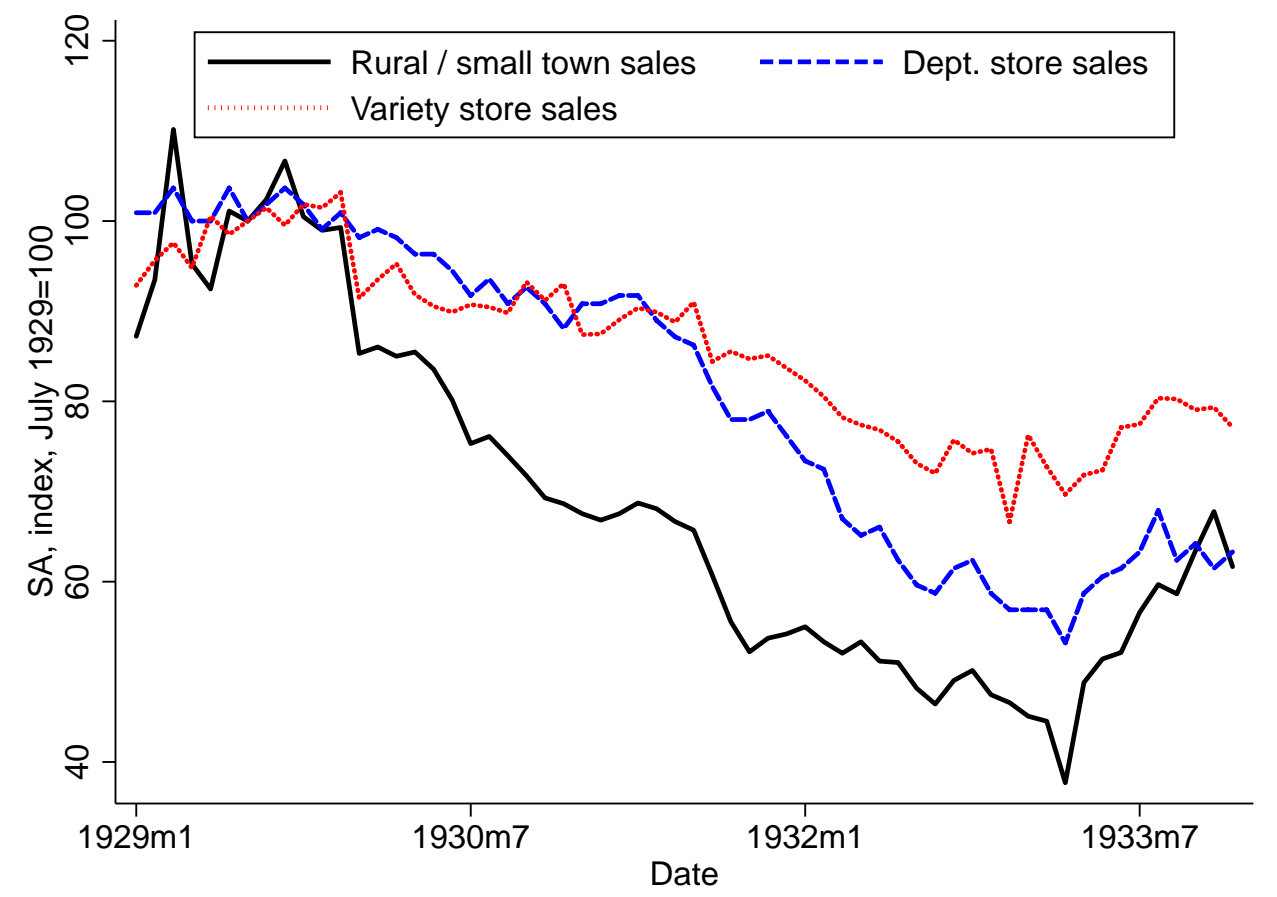

Sources: Pre-1932 department store sales - 9/1936 Survey of Current Business, p. 19; Pre-1932 rural sales - 12/1934 Survey of Current Business, p. 20; 1932-1933 department store and rural sales - 1936 Survey of Current Business Supplement, pp. 27-28; variety store sales - 3/1934 Survey of Current Business, p. 18.

While this is already evidence of a large relative decline in consumption in farm areas, we turn to state and county data in order to more precisely quantify the evolution of spending in farm versus nonfarm areas. In particular, we focus on data on auto sales. Auto sales have three advantages. First, the data are available monthly by state and monthly by county in Ohio. We know of no other indicator of expenditure available by state or county at this frequency. Second, the data are likely to be relatively well-measured, given that car registration was required. Finally, while only one component of household spending, cars played an outsized role in the initial year of the Great Depression. As emphasized by Romer 
(1990), in 1930 durables consumption fell much more than non-durables consumption.

3.1 Evidence from U.S. States Monthly data on new passenger car registrations come from the 1934 Automotive Daily News Review and Reference Book. ${ }^{13}$ These data closely approximate sales and for conciseness, we will generally refer to auto "sales" rather than "new registrations." States required the registration of new cars, so new registrations were a direct measure of sales. As discussed further in appendix C, at times the measure could be inexact, but only to a limited degree.

Figure 7 shows a scatter plot of the percent change in new registrations (sales) between the second and third quarter of 1929 and the second and third quarter of 1930 and the share of a state's population living on farms. Here and in our regressions below we compare car sales between these six-month averages (1929:Q2-Q3 and 1930:Q2-Q3), since doing so filters out idiosyncratic noise in the monthly data. Figure 7 shows a clear negative relationship between car sales growth and farm share of the population during the first year of the Great Depression.

Figure 8 provides another way to see the relationship between farm share and economic performance. It graphs the average level of auto sales in each of four quartiles of states, where states are grouped by the share of their population living on farms. ${ }^{14}$ By the second half of 1930, a clear pattern emerges, in which auto sales had fallen most in the highest farm share states (quartile 4) and least in the lowest farm share states (quartile 1). There is no evidence of divergence between the quartiles before early 1930, with the exception of a notable upward spike in auto sales in quartile 4 in late 1929. This upward spike is driven by very high auto sales in Alabama and Mississippi, numbers that we suspect may be errors. Appendix Figure D.1 shows that when Alabama and Mississippi are excluded, this upward spike disappears, but the monotonic pattern in which 1930 car sales fell most in the highest

\footnotetext{
${ }^{13}$ This was published as a supplement to the Automotive Daily News. The data are on pp. 22-23 and are labeled "New Passenger Car Registrations." The original source is listed as R.L. Polk \& Co., New Jersey Motor Co., and Sherlock \& Arnold.

${ }^{14}$ For this figure, we seasonally adjust auto sales using data from 1929 (when the series begins) through 1934, excluding 1933 because of the dramatic auto sales growth in spring 1933 (Hausman et al., 2019). We use data only through 1934, because thereafter the seasonal pattern of auto sales changed due to a change in the date of new model introduction (Cooper and Haltiwanger, 1993). Seasonally adjusted sales in month $t$ are $e^{\hat{\varepsilon}_{t}+\sum_{j=1}^{12} \hat{\beta}_{j} / 12}$, where $\hat{\varepsilon}_{t}$ is the residual from a regression of log auto sales on monthly dummies, and $\hat{\beta}_{j}$ is the OLS coefficient on the month $j$ dummy.
} 
Figure 7 - Percent change in car sales and farm population share

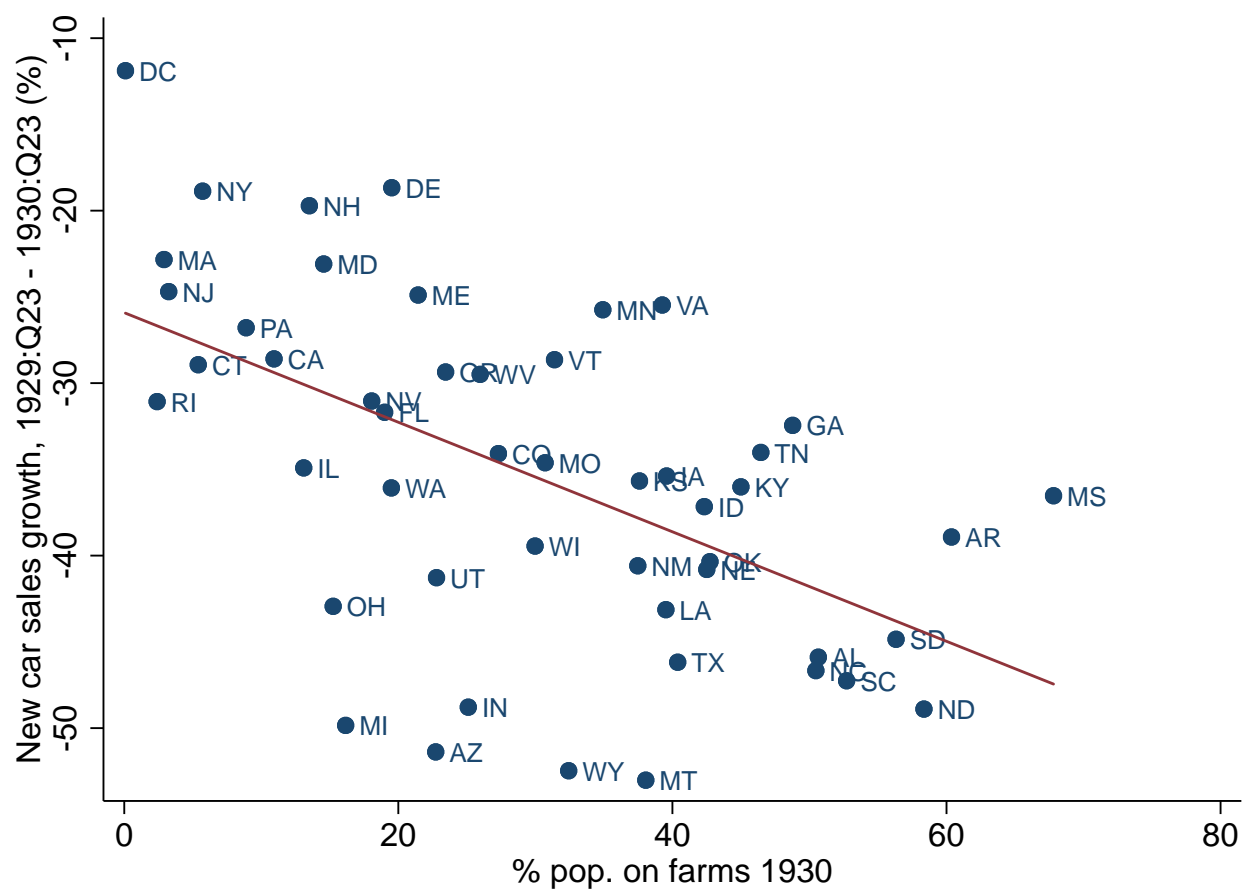

Sources: Car sales - see text; farm share of the population - Haines and ICPSR (2010).

farm share states remains. That the pattern of worse performance emerges in early 1930 and not before is consistent with the timing of farm product price declines; we saw in the previous section that farm product prices only began to rapidly decline in early 1930 .

Table 2 investigates the relationship between farm intensity and auto sales more carefully by estimating regressions of the form:

$$
\% \Delta \text { Auto sales }{ }_{i, 1929: \mathrm{Q} 2-\mathrm{Q} 3-1930: \mathrm{Q} 2-\mathrm{Q} 3}=\beta_{0}+\beta_{1} \text { Agricultural exposure }_{i}+\gamma^{\prime} X_{i}+\varepsilon_{i}
$$

where $\% \Delta$ Auto sales $_{i, 1929: Q 2-Q 3-1930: Q 2-Q 3}$ is auto sales growth in state $i$ at the beginning of the Depression, "Agricultural exposure" is a measure of a state $i$ 's exposure to falling farm prices, and $X$ is a set of control variables. Column 1 shows results for the single-variable regression analogous to the scatter plot in Figure 7. The coefficient is both economically and statistically significant (the t-statistic equals 5). The coefficient of -0.32 implies that a one standard deviation change in farm population share (17 percentage points) is associated with a 5.5 percentage point decline in auto sales growth. For comparison, nationwide auto 
Figure 8 - Car sales by farm share quartile

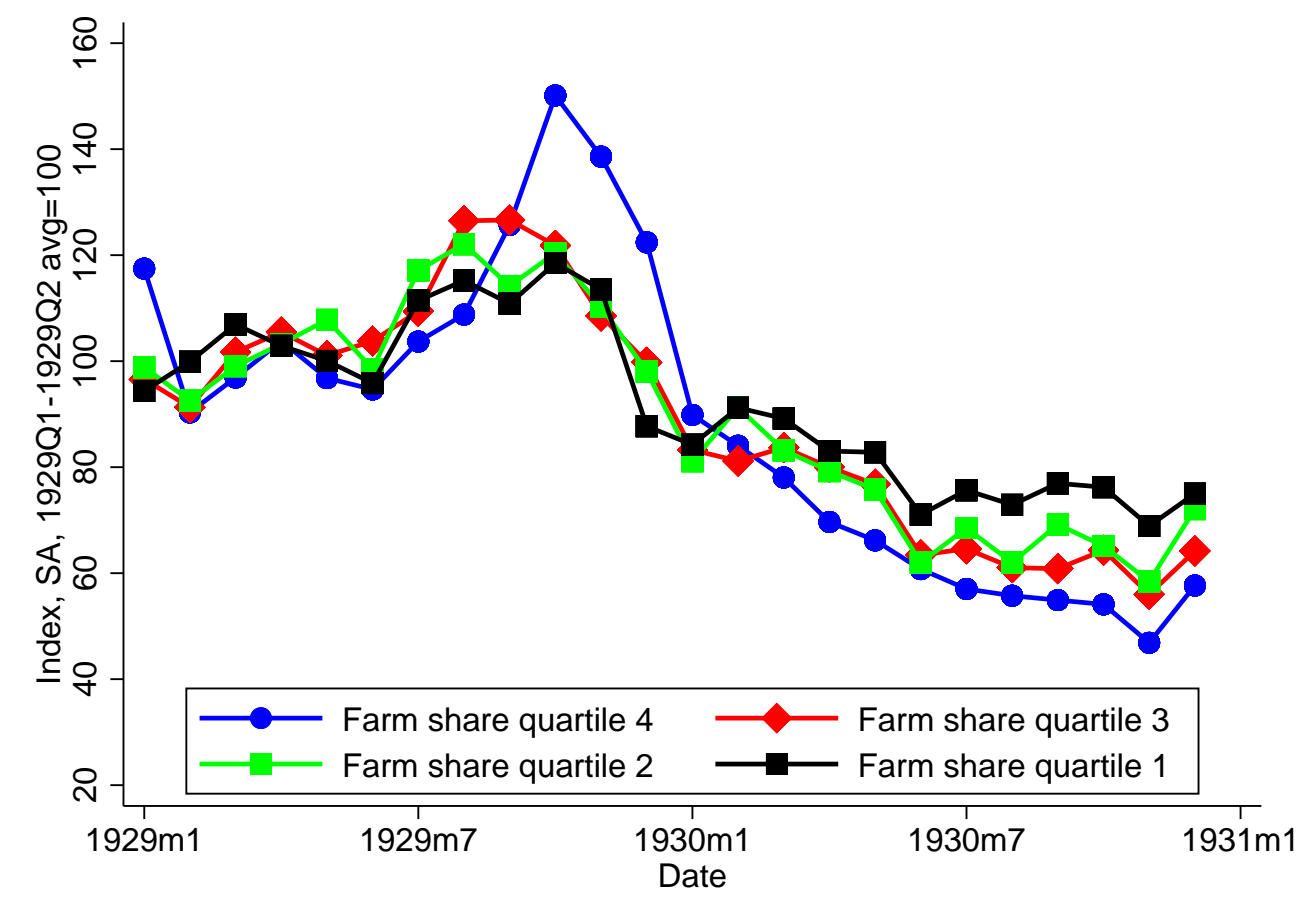

Sources: Car sales - see text; farm share of the population - Haines and ICPSR (2010).

sales fell 34 percent over this period. ${ }^{15}$ Note also that the $\mathrm{R}^{2}$ is 0.30 : as measured by auto sales, the farm share of the population alone explains 30 percent of the cross-state variation in the severity of the early Great Depression.

In interpreting the results in Table 2, it is worth emphasizing that specification 1 is not directly measuring the change in purchases of cars by farmers themselves; the difference we see between the change in car sales in more and less farm intensive states is due not only to the purchasing behaviour of farmers but also to the purchasing behaviour of segments of the population whose livelihood was linked to that of farmers. When farmers' spending fell, the owner of the local general store may have also foregone an auto purchase.

Column 2 adds control variables to address omitted variable bias concerns. We control for population to assure that the percent of state's population living on farms is not simply proxying for a small versus large state effect; ${ }^{16}$ we control for the per-capita number of cars sold in 1928 to assure that estimates are not biased by greater propensities to purchase cars

\footnotetext{
${ }^{15}$ Nationwide new auto sales are from NBER macrohistory series m01109.

${ }^{16}$ As a further check for the influence of small versus large states on our results, appendix Table F.1 replicates Table 2, but weighting by population. Estimates are qualitatively similar.
} 
Table 2 - Cross-state regressions

\begin{tabular}{|c|c|c|c|c|c|c|}
\hline & $(1)$ & $(2)$ & $(3)$ & $(4)$ & $(5)$ & $(6)$ \\
\hline \multicolumn{7}{|l|}{ Right hand side variables: } \\
\hline \% pop. on farms 1930 & $\begin{array}{c}-0.32^{* * *} \\
(0.064)\end{array}$ & $\begin{array}{c}-0.34^{* * *} \\
(0.082)\end{array}$ & $\begin{array}{c}-0.39^{* * *} \\
(0.10)\end{array}$ & & & \\
\hline Crops sold p.c. 1929 (\$s) & & & & $\begin{array}{c}-0.12^{* * *} \\
(0.031)\end{array}$ & $\begin{array}{c}-0.080^{* *} \\
(0.033)\end{array}$ & $\begin{array}{c}-0.097^{* *} \\
(0.038)\end{array}$ \\
\hline Population 1930 (millions) & & $\begin{array}{c}-0.48 \\
(0.54)\end{array}$ & $\begin{array}{r}-0.53 \\
(0.55)\end{array}$ & & $\begin{array}{r}-0.097 \\
(0.51)\end{array}$ & $\begin{array}{r}-0.078 \\
(0.55)\end{array}$ \\
\hline 1928 car sales p.c. $(1000$ s) & & $\begin{array}{r}-0.098 \\
(0.23)\end{array}$ & $\begin{array}{r}-0.14 \\
(0.25)\end{array}$ & & $\begin{array}{c}0.23 \\
(0.29)\end{array}$ & $\begin{array}{c}0.26 \\
(0.29)\end{array}$ \\
\hline 1930 drought & & & $\begin{array}{c}-3.13 \\
(2.98)\end{array}$ & & & $\begin{array}{c}-1.25 \\
(3.07)\end{array}$ \\
\hline 1929 drought & & & $\begin{array}{l}10.8^{* *} \\
(4.09)\end{array}$ & & & $\begin{array}{l}12.6^{* *} \\
(4.92)\end{array}$ \\
\hline Region Fixed Effects & No & Yes & Yes & No & Yes & Yes \\
\hline$R^{2}$ & 0.30 & 0.49 & 0.55 & 0.24 & 0.39 & 0.47 \\
\hline Observations & 49 & 49 & 49 & 49 & 49 & 49 \\
\hline
\end{tabular}

Notes: The dependent variable is the percent change in non-seasonally adjusted car sales from the 1929:Q2Q3 average to the 1930:Q2-Q3 average. p.c. means per capita. Robust standard errors in parenthesis. ${ }^{*} p<0.1,{ }^{* *} p<0.05,{ }^{* * *} p<0.01$. Sources: New car sales - see text; population and percent of the population on farms - the 1930 Census as reported in Haines and ICPSR (2010); 1929 value of crops sold per capita - the 1940 Census as reported in Haines, Fishback, and Rhode (2015); 1928 car sales - Automotive Industries, $2 / 23 / 29$, p. 271; we construct the drought dummies using data from the National Climate Data Center. Region fixed effects are dummy variables for the four census regions - northeast, midwest, south, and west.

in some states; and we control for region fixed effects to isolate the effects of farm intensity within regions. These control variables have essentially no effect on the coefficient. Column 3 controls for drought with two dummy variables equal to 1 in states that suffered a moderate drought or worse in the second and third quarters of 1930 and 1929. ${ }^{17}$ With the controls for drought, the coefficient on farm share of the population is again little changed.

Column 4 of Table 2 uses an alternative indicator of a state's agricultural exposure: the value of crops sold per capita in 1929. The coefficient is again economically and statistically significant (t-statistic equal to 4). The coefficient of -0.12 implies that a one-standard deviation increase in crops sold per capita in a state $(\$ 39.70)$ results in a 4.8 percentage point

\footnotetext{
${ }^{17}$ These are states with an average Palmer drought index of -2 or below between April and September 1930 / 1929. For a narrative account of the 1930 drought and its impact on agriculture, see United States Department of Agriculture (1931).
} 
larger decline in auto sales in the first year of the Depression. This is very similar to the decline in auto sales associated with a one standard deviation change in farm share of the population. Column 5 adds control variables and region fixed effects. The coefficient shrinks by one third, but remains economically and statistically significant. Column 6 adds controls for drought. This results in an increase in the coefficient on crops sold per capita.

The results in Table 2 show that agricultural-intensive states suffered more during the first year of the Great Depression. This is consistent with a story in which lower agricultural prices depressed farm incomes and farm consumption and investment. We would also like to know what sort of farm areas did worst in 1930. If spending declined most in areas growing crops whose prices declined most, this would support our argument that lower farm product prices and income lowered farm area spending. To investigate this, we look at how state performance varied with the type of agricultural product produced.

3.1.1 Results by crop Table 3 shows the relationship between the auto sales growth in the first year of the Depression and the production of two categories of farm products: internationally traded crops and nontraded farm products. In distinguishing between traded and nontraded farm products, our goal is to distinguish between those farm products whose prices were likely to be strongly influenced by world demand (e.g. cotton) from those less influenced by world demand (e.g. milk). This roughly captures the difference between farm products whose prices collapsed in 1930 and those whose prices fell more modestly (Table 1 and Figure 3). We define traded crops to be the value of cotton, tobacco, cereals, and wool production. While not all cereals were traded, their substitutability meant that their prices often moved together (Hausman et al., 2019). Nontraded farm production equals nontraded crop production plus the value of dairy and livestock sold. Nontraded crop production is equal to the value of total crop production minus the value of traded crops. We also include corn in the nontraded crops category. Corn is a cereal, and corn prices may have moved with other cereals prices; but movements in corn prices did not necessarily directly impact farm incomes, because corn was often grown to feed hogs. An increase in the market price of corn had little or no effect on many corn farmers' incomes, since the same farmers were using the corn to feed their hogs. 
Table 3 - Cross-state regressions by farm product type

\begin{tabular}{lccc}
\hline & $(1)$ & $(2)$ & $(3)$ \\
\hline Right hand side variables: & & & \\
Cotton, tobacco, cereals, wool p.c. $1929(\$ \mathrm{~s})$ & $-0.15^{* * *}$ & $-0.12^{* * *}$ & $-0.12^{* * *}$ \\
& $(0.034)$ & $(0.038)$ & $(0.042)$ \\
Nontraded farm products p.c. $1929(\$ \mathrm{~s})$ & -0.0025 & 0.024 & 0.016 \\
& $(0.012)$ & $(0.023)$ & $(0.027)$ \\
Population 1930 (millions) & & -0.016 & -0.029 \\
& & $(0.49)$ & $(0.52)$ \\
1928 car sales p.c. (1000s) & & 0.13 & 0.18 \\
& & $(0.31)$ & $(0.32)$ \\
1930 drought & & -0.95 \\
1929 drought & & & $(3.20)$ \\
& & & $10.5^{* *}$ \\
Region Fixed Effects & No & Yes & Yes \\
$R^{2}$ & 0.34 & 0.48 & 0.53 \\
Observations & 49 & 49 & 49 \\
\hline \hline
\end{tabular}

Notes: The dependent variable is the percent change in non-seasonally adjusted car sales from the 1929:Q2Q3 average to the 1930:Q2-Q3 average. Corn is included in nontraded crops because of its use in hog production. p.c. means per capita. Robust standard errors in parenthesis. ${ }^{*} p<0.1,{ }^{* *} p<0.05,{ }^{* * *} p<0.01$. Sources: per capita farm product production - the 1940 Census as reported in Haines et al. (2015); all other variables - see Table 2 .

The first column of Table 3 shows that traded crop production was much more correlated with auto sales than was nontraded farm product production. The coefficient on traded crop production of -0.15 implies that a one-standard deviation increase in traded crop production (\$39) would have resulted in 5.7 percentage points lower auto sales growth. The coefficient is estimated precisely, with a t-statistic above 4 and a 95 percent confidence interval of [$0.21,-0.08]$. Thus we can be confident that there was an economically significant relationship between traded crop production and economic performance.

By contrast, conditional on traded crop production, there is no evidence of a negative association between nontraded farm product production and car sales growth in the first year of the Depression. The conclusion remains the same in columns (2) and (3) when we add control variables. In sum, the cross-state results show that it was traded crop production rather than agricultural production as a whole that was associated with a more severe beginning of the Depression. This is consistent with the much larger declines in traded 
crop prices than in the prices of farm products as a whole.

3.2 Evidence from Ohio counties To obtain further evidence on the relationship between agriculture and the severity of the early Great Depression, we collected data on new car registrations in Ohio counties. To our knowledge, these are the only available county-level data on new car registrations at an annual or higher frequency in 1929-30. The data for Ohio come from the Bulletin of Business Research prepared by the College of Commerce and Administation of the Ohio State University. The data are monthly and are presented as "Registrations of New Automobile Bills of Sales in Ohio Counties" with the source specified as "Clerks of Courts of Listed Counties."18 Unfortunately, the data do not cover all counties: we have data for 50 of the 88 counties in Ohio. But these counties accounted for most car sales; in 1928, more than 80 percent of all new car sales in Ohio occurred in these 50 counties. $^{19}$

The Bulletin of Business Research presents data on both new passenger car sales and new truck sales. Unfortunately, however, there are too few counties with substantial truck sales to make the truck sales data useful for understanding the early Great Depression. Thus we confine ourselves to an analysis of the new passenger car sales. This has the added advantage of easy comparability with the our cross-state results, which are also only for passenger cars.

Figure 9 presents a cross-county scatter plot analogous to the cross-state scatter plot in Figure 7. Across Ohio counties, there is no clear relationship between farm population share and new car sales growth. Close inspection of the data, however, reveal that the null result is driven by a few counties, in particular, Gallia, Geauga, and Union. These three counties had large portions of their population living on farms but relatively low values of crop production. As discussed above, it is crop producing areas that we expect to have suffered most at the beginning of the Depression, because crop prices fell more than farm product prices as a whole. Figure 10 thus shows a similar scatter plot, but with the value of crops sold per capita rather than the proportion of the population living on farms on the

\footnotetext{
${ }^{18}$ See, for example, Bulletin of Business Research, May 1930, table II, p. 6. See the appendix for details on the editions of the Bulletin of Business Research used to assemble the data.

${ }^{19}$ County car sales in 1928 are calculated from the Industrial and Commercial Ohio Yearbook (1930), table XVI, p. 104 which lists by county both 1929 car sales and the 1928-29 percent change in car sales. The state total is from Automotive Industries, 2/23/29, p. 271.
} 
Figure 9 - Ohio counties: Percent change in new car sales and farm population share

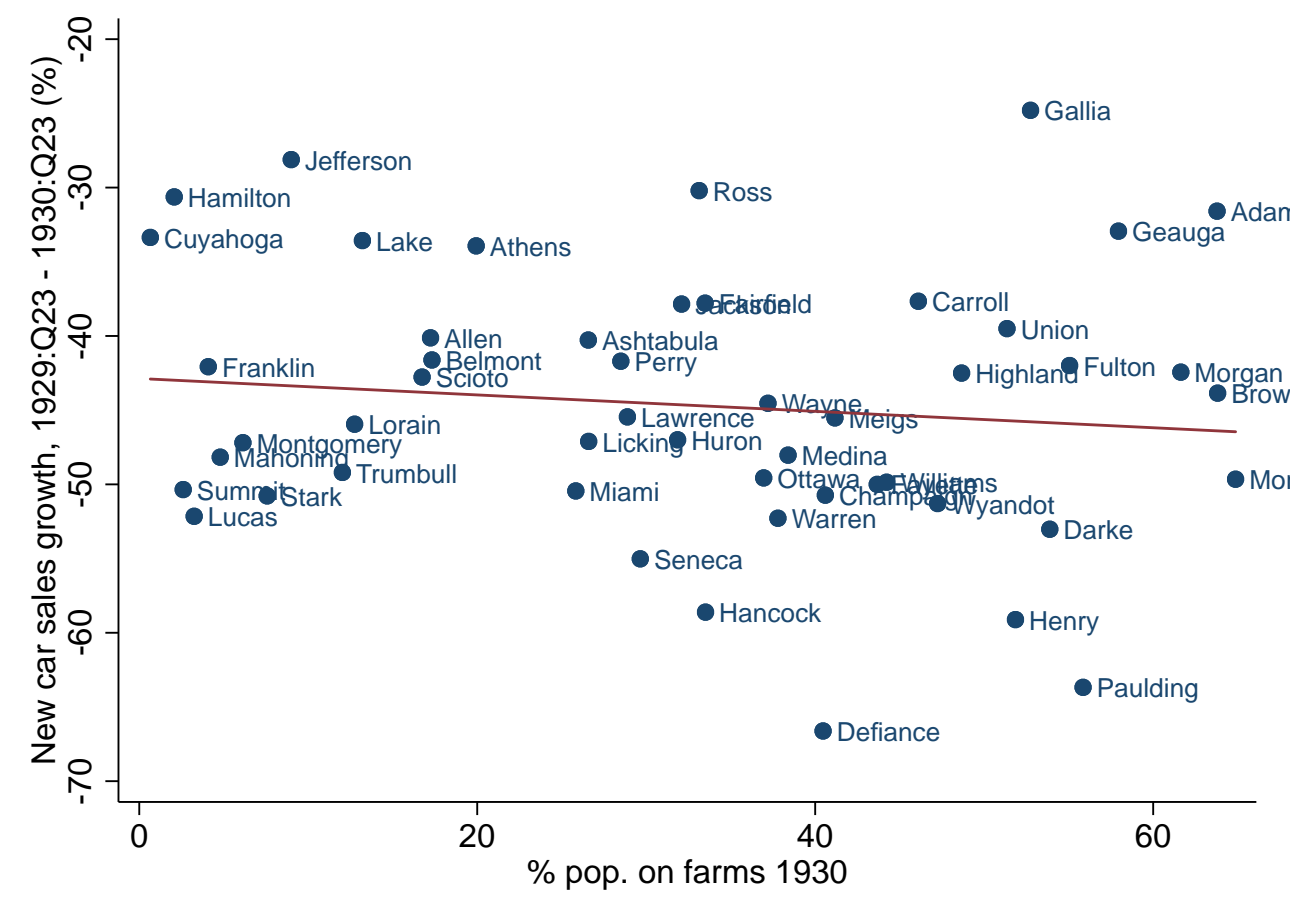

Sources: Car sales - see text; farm share of the population - Haines and ICPSR (2010).

$\mathrm{x}$-axis. As expected, here there is a more obvious negative relationship. This results in part from the shift of Gallia, Geauga, and Union counties from the far right of the graph to near the middle, reflecting their mid-range crop production despite large farm population shares.

To more formally investigate the relationship in Ohio between agricultural intensity and performance early in the Depression, we run regressions across counties like those estimated across states in the previous section. Specifically, we estimate

$$
\% \Delta \text { Auto sales }{ }_{j, 1929: \mathrm{Q} 2-\mathrm{Q} 3-1930: \mathrm{Q} 2-\mathrm{Q} 3}=\beta_{0}+\beta_{1} \text { Agricultural exposure }_{j}+\gamma^{\prime} X_{j}+\varepsilon_{j},
$$

where $\% \Delta$ Auto sales ${ }_{j, 1929: Q 2-Q 3-1930: Q 2-Q 3}$ is new auto sales growth in county $j$ at the beginning of the Depression, "Agricultural exposure" is a measure of exposure to falling farm product prices, and $X$ is a set of control variables.

Columns (1) and (2) of Table 4 show the single variable regressions corresponding to the scatter plots in Figures 9 and 10. Columns (3) and (4) add controls for population and 1928 car sales per capita. Unsurprisingly given the scatter plot (Figure 9), with and without controls the coefficient on farm share is small and insignificant. By contrast, with 
Figure 10 - Ohio counties: Percent change in new car sales and value of crops sold per capita

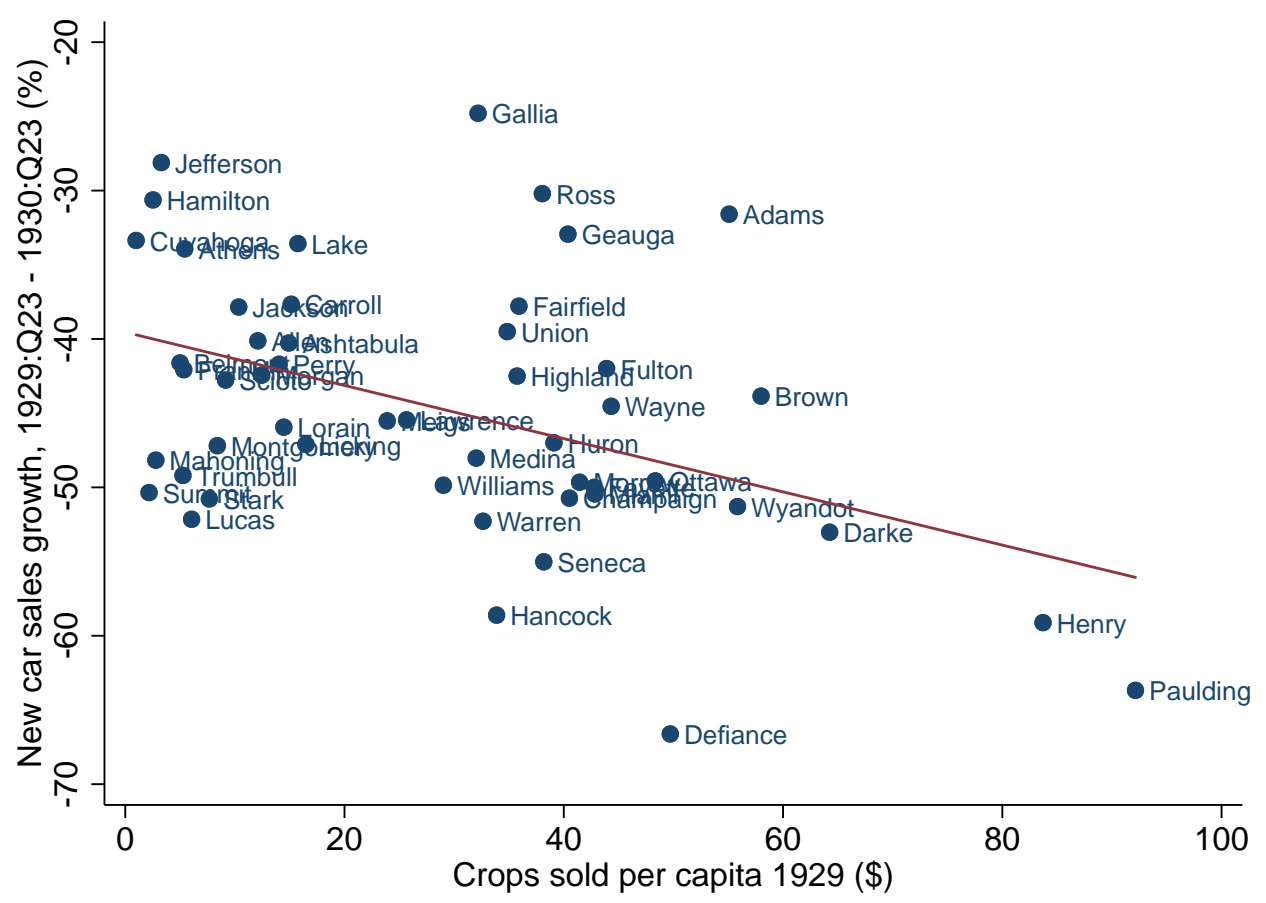

Sources: Auto sales - see text. Crops sold per capita - Haines et al. (2015).

and without controls, the coefficient on crop sales per capita is economically and statistically significant. Its magnitude (-0.13) is somewhat larger than that in the cross-state regression with these controls (column 5 of Table 2). Thus the results support the cross-state finding of an economically significant relationship between the importance of crops in a county and the depth of the Depression in 1929-30. Columns (5) and (6) explore the relationship between traded and nontraded farm product production and auto sales. As in the cross-state results in Table 3, across Ohio counties, the negative impacts of agriculture are driven by the cultivation of traded crops. But the conclusion is more tentative in the Ohio county data than it is in the state data, since when controls are added (column 6) the coefficient on traded crops loses statistical significance.

Unlike the state results which change little when weighted by population (appendix Table F.1), some of the cross-county specifications are sensitive to population weighting. Specifically, appendix Table F.2 shows that the univariate results (specifications (1) and (2)) become stronger, with more evidence of a negative relationship between farm share / crops sold per capita and auto sales. But the results with controls (specifications (3) and 
Table 4 - Cross-county regressions

\begin{tabular}{|c|c|c|c|c|c|c|}
\hline & $(1)$ & $(2)$ & $(3)$ & $(4)$ & $(5)$ & $(6)$ \\
\hline Farm share $1930(\%)$ & $\begin{array}{r}-0.062 \\
(0.075)\end{array}$ & & $\begin{array}{r}-0.029 \\
(0.086)\end{array}$ & & & \\
\hline Crop value sold p.c. $1929(\$)$ & & $\begin{array}{c}-0.18^{* * *} \\
(0.052)\end{array}$ & & $\begin{array}{r}-0.13^{* *} \\
(0.059)\end{array}$ & & \\
\hline Cotton, tobacco, cereals, wool p.c. 1929 & & & & & $\begin{array}{r}-0.24^{*} \\
(0.12)\end{array}$ & $\begin{array}{r}-0.16 \\
(0.11)\end{array}$ \\
\hline Nontraded farm products p.c. 1929 & & & & & $\begin{array}{c}0.015 \\
(0.032)\end{array}$ & $\begin{array}{c}0.012 \\
(0.029)\end{array}$ \\
\hline Population 1930 (millions) & & & $\begin{array}{c}7.22 \\
(5.10)\end{array}$ & $\begin{array}{c}2.16 \\
(5.16)\end{array}$ & & $\begin{array}{c}4.25 \\
(4.96)\end{array}$ \\
\hline 1928 car sales p.c. (1000s) & & & $\begin{array}{c}-0.46^{* * *} \\
(0.15)\end{array}$ & $\begin{array}{c}-0.39^{* *} \\
(0.15)\end{array}$ & & $\begin{array}{c}-0.38^{* *} \\
(0.15)\end{array}$ \\
\hline$R^{2}$ & 0.02 & 0.19 & 0.28 & 0.35 & 0.19 & 0.34 \\
\hline Observations & 49 & 49 & 49 & 49 & 49 & 49 \\
\hline
\end{tabular}

Notes: The dependent variable is the percent change in non-seasonally adjusted new car registrations from the 1929:Q2-Q3 average to the 1930:Q2-Q3 average. p.c. means per capita. While we observe monthly new registrations in 1929-30 in 50 counties, there are only 49 observations since 1928 registrations were not reported for Morgan county. Robust standard errors in parenthesis. ${ }^{*} p<0.1,{ }^{* *} p<0.05,{ }^{* * *} p<0.01$. Sources: New car registrations - see text; population and percent of the population on farms - the 1930 Census as reported in Haines and ICPSR (2010); 1929 value of crops sold per capita and farm product categories - the 1940 Census as reported in Haines et al. (2015); 1928 car sales - calculated from the Industrial and Commercial Ohio Yearbook (1930), table XVI, p. 104 which lists by county both 1929 car sales and the 1928-29 percent change in car sales.

(4)) become weaker. When weighted, there is no longer a negative coefficient on crops sold per capita. Reassuringly, weighting strengthens the finding in columns (5) and (6) that traded crop production drove worse economic performance while nontraded farm product production did not.

Taken together, the cross-county data are supportive of the findings from the crossstate data. The county sample is too small and noisy for precise, statistically significant conclusions in all specifications, but the results support the robust message from the crossstate data that areas producing traded crops suffered most in the first year of the Depression.

3.3 Narrative evidence Further evidence for the effect of lower farm product prices on car sales in farm areas comes from narrative evidence. Narrative evidence itself does not establish the importance of a channel from farm product prices to car sales. But combined 
with the quantitative evidence above, it is reassuring. That contemporaries noticed the channel from farm product prices to auto sales suggests that the effect was significant; it supports the mechanism we posit, in which lower farm product prices reduced farmers' incomes and hence their expenditure.

Narrative evidence comes from the publication Automobile Topics which reported on car sales conditions around the country. In summer and fall 1930, it reports many instances of lower farm product prices depressing sales. The 2 August 1930 edition includes these reports:

- "IOWA - Grain prices are too low. Farmers will not buy" (p. 1028).

- "MICHIGAN - Better prices for agricultural products would help sales" (p. 1028).

- "SOUTH DAKOTA - Prices of farm products hurting our business" (p. 1028).

Similar comments were made in the 4 October 1930 issue:

- "SOUTH CAROLINA - Prices on cotton and tobacco retarding sales" (p. 678).

- "GEORGIA - Low price of cotton hurting" (p. 678).

- "NORTH DAKOTA - Poor crops and low grain prices retarding sales. There can be no prosperity here until grain prices go up" (p. 678).

To be sure - and consistent with our argument - low farm product prices are far from the only factor discussed in Automobile Topics. Many quotes are also to be found on depressed conditions in manufacturing, on complaints about banks, and on idiosyncratic local conditions. Like our quantitative evidence, however, the narrative evidence is consistent with a large role for lower farm product prices in explaining lower auto sales in 1930.

\section{Redistribution}

Lower farm product prices transferred income from the farm sector to the rest of the economy, and we have shown that spending fell in farm relative to nonfarm areas. This does not establish, however, that lower farm product prices had a negative impact on the 
economy as a whole. Like Madsen (2001), we believe that a mechanism through which the transfer of income away from farmers was on net contractionary is that farmers likely had a higher MPC than the agents benefitting from lower farm product prices.

Unlike the econometric evidence of the previous sections, the evidence for a relatively high MPC among farmers is fragmentary. The first piece of evidence is farmers' debt burden. As the quote from Irving Fisher that begins this paper suggests, low farm product prices and incomes posed particularly severe problems for farmers because of large nominal debt burdens. In 1930, farm mortgage debt was 190 percent of net farm personal income. ${ }^{20}$ By comparison, residential mortgage debt was 39 percent of nonfarm personal income. ${ }^{21}$ High farm debt burdens were reflected in large numbers of farm foreclosures. In 1929 and 1930, there were 14.7 and 15.7 foreclosures per 1000 farms. This indicates a severe level of distress relative to more normal times; foreclosures per 1000 farms averaged just 3.2 in both the 1913-20 period and the 1941-1950 period (Alston (1983), table 1, p. 888).

These debt problems were long in the making. Farmers acquired debt during World War I as farm product prices and farm land values rose. Nominal debt continued to rise in the 1920s even as farm product and farm land prices fell (Wickens, 1932; Alston, 1983). This put farmers in a perilous position on the eve of the Great Depression; hence when farm product prices fell in 1929-1930, real farm debt burdens rose to very high levels. Table 5 shows that the ratio of farm debt to gross income and the ratio of farm debt to assets roughly doubled between 1910 and 1930. The debt to gross income ratio increased by 20 percent just between 1928 and 1930.

Table 5 - Farm Debt

\begin{tabular}{ccc}
\hline year & Debt / Gross income (\%) & Debt / Assets (\%) \\
\hline 1910 & 50 & 9 \\
1920 & 58 & 13 \\
1928 & 81 & 20 \\
1930 & 98 & 21 \\
1932 & 162 & 25 \\
\hline
\end{tabular}

Notes: Debt is farm mortgage debt. Assets are the value of farm land and buildings. Source: Clark (1933), table 5, p. 28.

\footnotetext{
${ }^{20}$ Nominal mortgage debt data are from U.S. Department of Commerce (1975), series K157, p. 466; income data are from BEA table SA4.

${ }^{21}$ Snowden (2006) and BEA table SA4.
} 
One would expect these large nominal debt burdens to have increased the difficulties farmers faced from lower farm product prices in 1930. As farmers' incomes fell, debt service absorbed more of their income, squeezing their spending. Olney (1999) argues that a similar mechanism affected households burdened by consumer debt, contributing to the economywide collapse of spending in 1930. To understand the contribution of farm mortgage debt to the collapse of spending in farm states, we start by examining the univariate relationship between auto sales over our sample period (1929:Q2-Q3 to 1930:Q2-Q3) and farm leverage in a state, with leverage defined as $\frac{\text { assets }}{\text { assets-debt }}$, where debt is equal to farm mortgage debt, and assets are equal to the value of farm land and buildings.

Figure 11 - Percent change in car sales and farm leverage

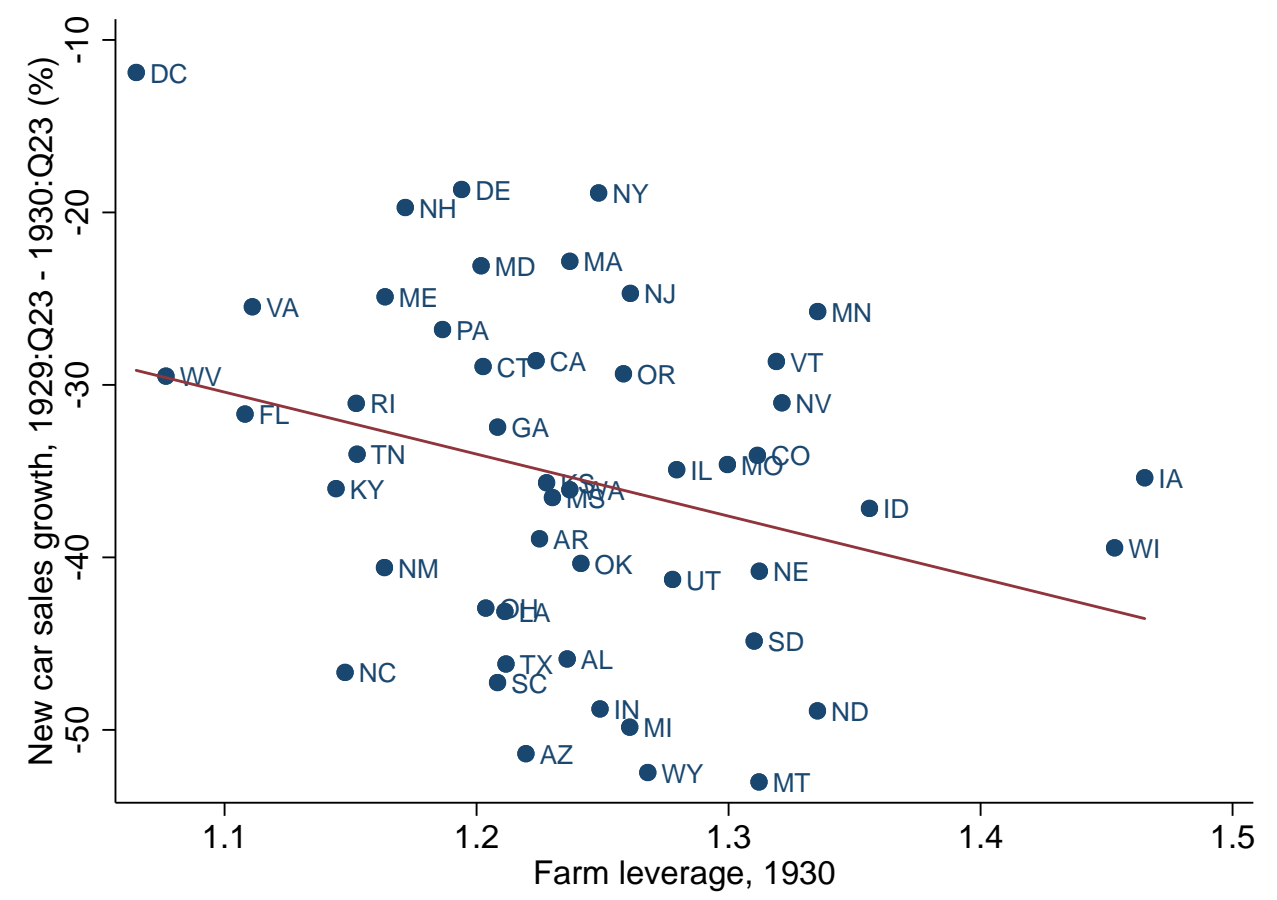

Source: Car sales - see text; farm leverage - authors' calculations from data on debt and assets in Haines et al. (2015).

Figure 11 shows a scatter plot of this relationship. There is some evidence of a negative relationship, though it is not statistically significant when Washington D.C. (an obvious outlier with little agriculture) is excluded. Of more interest than this bivariate relationship would be whether the interaction of traded crop production and farm leverage was a determinant of auto sales in 1930. (We focus on traded crops because those are the farm products whose prices fell most.) The hypothesis - consistent with Olney (1999) — is that the negative 
effect of traded crop production on auto sales would have been largest in those areas with the most farm leverage. In other words, we expect farmers to have cut back most on spending in response to farm product price declines in places where their debt burdens were heaviest.

To test this hypothesis we would like to estimate:

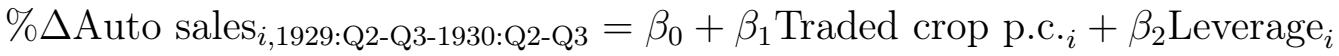

$$
\begin{aligned}
& +\beta_{3} \text { Traded crop p.c. }{ }_{i} \times \text { Leverage }_{i}+\gamma^{\prime} X_{i}+\varepsilon_{i} \text {. }
\end{aligned}
$$

The problem is that with 49 observations we lack the statistical power to do this estimation; in our 49 observation sample, there is essentially no variation in the interaction term that is not explained by the level of traded crop production and leverage. The $\mathrm{R}^{2}$ of the regression of the interaction on the levels of traded crop production and leverage is 0.998. Thus we cannot plausibly identify $\beta_{3}$.

Despite our inability to estimate equation 3 , we have three reasons to believe that $\beta_{3}$ is negative, that more debt was associated with a larger decline in spending when farm product prices fell. First, a negative $\beta_{3}$ is predicted by theory. Second, in Hausman et al. (2019) we estimate a regression similar to (3) on nationwide county auto sales data in 1933, a time when farm product prices rose; we find that higher farm product prices had a larger effect on spending in counties where more farms were mortgaged. Third, recent evidence from the 2008 financial crisis suggests that more leverage was associated with larger declines in household consumption (Mian, Rao, and Sufi, 2013).

The second argument suggesting that farmers had a relatively high MPC concerns the distribution of the benefits of lower farm product prices. Insofar as lower farm product prices benefited urban workers, many of whom were losing their jobs in 1930, it is not obvious that the difference between the MPCs of the winners and losers would be large. Limited passthrough meant, however, that it was businesses as well as workers who benefited from lower farm product prices. And it is quite plausible that the marginal propensity to spend of businesses was much below that of farmers. ${ }^{22}$

\footnotetext{
${ }^{22}$ Some of the farm products whose prices fell most, such as cotton and tobacco (Table 1), were exported in large quantities. This meant that some of the benefit of lower farm product prices accrued to households and businesses abroad. In the same way, however, U.S. households and businesses benefited from lower prices of imported agricultural goods, such as coffee, sugar, and rubber. U.S. trade in agricultural products was roughly balanced; therefore, there was likely to have been a rough balance between the exported and
} 
Limited pass-through was driven by the stickiness of many final goods prices at the beginning of the Depression. For example, while the producer price of tobacco fell 23 percent from 1929-1930, the price of a pack of cigarettes rose 2 percent. ${ }^{23}$ Retail bread prices fell 0.17 cents per pound while the price of the farm product input fell 0.26 cents. $^{24}$ And while the price of the wheat input to a $28-\mathrm{oz}$ package of wheat cereal fell by 0.8 cents between 1929:Q2-Q3 and 1930:Q2-Q3, the retail price fell only 0.2 cents (United States Department of Agriculture (1945), table 42, p. 195). These (and other) examples suggest that in 1930 businesses producing final goods from farm products often benefited from lower farm product prices. $^{25}$

\section{Aggregate effect}

To obtain a quantitative sense of how farmers' relatively high MPC could have led to aggregate effects of lower farm product prices, we follow Hausman et al. (2019). There we argued that the aggregate effect of a farm product price change on car sales can be approximated by

$$
\begin{aligned}
\% \Delta \text { Cars }= & \underbrace{\beta \times \phi^{f}}_{\begin{array}{c}
\text { "naive" } \\
\text { extrapolation }
\end{array}} \times \underbrace{\frac{\text { Farm area income per capita }}{\text { National income per capita }}}_{\text {Relative income p.c. }} \times \underbrace{\left(1-\xi \frac{\theta^{w}}{\theta^{f}}\right)}_{\begin{array}{c}
\text { Redistribution from } \\
\text { high-MPC consumers }
\end{array}} \times \underbrace{\mu_{t}}_{\begin{array}{c}
\text { Aggregate } \\
\text { spending } \\
\text { multiplier }
\end{array}} \\
& +\underbrace{-\sigma d \ln \left(1+r_{t}\right)}_{\text {Intertemporal Substitution }} .
\end{aligned}
$$

$\beta$ is the coefficient from the cross-state regression of the percent change in car sales on the farm share of the population. From column 1 of Table 2 this is $-0.32 . \phi^{f}$ is the farm share of the U.S. population, which in 1930 was 24.8 percent. We call the product of $\beta$ and

imported benefits of lower farm product prices. (In 1928-29, U.S. agricultural exports totaled $\$ 1.8$ billion, imports $\$ 2.2$ billion (United States Department of Agriculture, 1936, table 421, p. 292).) So we do not consider redistribution between the U.S. and foreign countries in our aggregate analysis below. We are indebted to Walker Hanlon for alerting us to this issue.

${ }^{23}$ These are the average of cigarette prices in June and December of each year. See United States Department of Labor (1936) (table 13, p. 241).

${ }^{24}$ This is the change in the urban price of a pound of white bread, from United States Department of Labor (1938), table 7, p. 78; data on the cost of the farm input is from United States Department of Agriculture (1945), table 32, p. 162.

${ }^{25}$ For more discussion and data on pass-through from farm prices to retail prices, see United States Department of Treasury, Bureau of Internal Revenue (1937). 
$\phi^{f}$ a naive extrapolation, since it is what one would guess about the aggregate effect from assuming that the aggregate effect of farmers on economic performance was exactly equal to the cross-sectional effect.

As discussed above, this naive extrapolation is wrong since the cross-sectional coefficient measures both the negative effect of lower farm product prices on farmers and the positive effect of lower farm product prices on nonfarmers. We assume that there are two types of nonfarmers: capitalists and workers. By assumption, capitalists have a MPC of zero, so that gains from lower farm product prices absorbed by businesses have no effect on aggregate demand. Thus, for instance, we assume that the gains of cigarette manufacturers from lower tobacco prices do not lead to more investment spending by cigarette manufacturers. Nonfarm workers, by contrast, do have a positive MPC, and we assume that they spend a substantial fraction of their gains from lower farm product prices. We believe this assumption to be reasonable given, for instance, the evidence in Gelman, Gorodnichenko, Kariv, Koustas, Shapiro, Silverman, and Tadelis (2019) on consumers' spending response to lower gas prices in 2014-2015; Gelman et al. (2019) find an MPC near 1 from the increase in income due to lower gas prices. While gas prices may be uniquely salient, it is likely that lower farm product prices, insofar as they passed through to lower consumer (e.g. food) prices did increase real worker spending, including that on cars.

These assumptions are reflected in our adjustment for redistribution. ${ }^{26}$ The adjustment factor, $\xi \frac{\theta^{w}}{\theta^{f}}$, equals the extent to which lower farm product prices were passed through to workers $(\xi)$ times the ratio of the marginal propensity to consume of workers $\left(\theta^{w}\right)$ to the marginal propensity to consume of farmers $\left(\theta^{f}\right)$. As in Hausman et al. (2019), we consider a range of values for the redistribution factor, $\xi \frac{\theta^{w}}{\theta^{f}}$, of 0.3 to 0.7 , and a range for the aggregate spending multiplier of 1 to 3 . Also as in Hausman et al. (2019), we ignore the possible quantitative contribution of intertemporal substitution, i.e. the contractionary effect of lower inflation expectations caused by lower farm product prices.

The results of this exercise are shown in Table 6. Columns (2) through (4) show the

\footnotetext{
${ }^{26}$ The adjustment for the ratio of farm area income per capita to national income per capita is a mechanical adjustment made necessary by the fact that farm areas tended to be poorer than nonfarm areas, and thus cross-sectional estimates exaggerate the aggregate effect of farmers on the national economy. See Hausman et al. (2019) for further discussion.
} 
Table 6 - Implied aggregate effect

\begin{tabular}{|c|c|c|c|c|c|c|}
\hline \multirow{3}{*}{$\begin{array}{l}\text { Redistribution from high } \\
\text { MPC consumers, } \xi \frac{\theta^{w}}{\theta^{f}}\end{array}$} & \multicolumn{3}{|c|}{ Predicted $\% \Delta$ Cars } & \multicolumn{3}{|c|}{ Fraction of actual $\% \Delta$ Cars } \\
\hline & \multicolumn{3}{|c|}{ Aggregate Multiplier } & \multicolumn{3}{|c|}{ Aggregate Multiplier } \\
\hline & $\mu=1$ & $\mu=2$ & $\mu=3$ & $\mu=1$ & $\mu=2$ & $\mu=3$ \\
\hline 0.7 & -1.6 & -3.2 & -4.7 & 4.7 & 9.4 & 13.8 \\
\hline 0.6 & -2.1 & -4.2 & -6.3 & 6.2 & 12.4 & 18.5 \\
\hline 0.5 & -2.6 & -5.3 & -7.9 & 7.6 & 15.6 & 23.2 \\
\hline 0.4 & -3.2 & -6.3 & -9.5 & 9.4 & 18.5 & 27.9 \\
\hline 0.3 & -3.7 & -7.4 & -11.1 & 10.9 & 21.8 & 32.6 \\
\hline
\end{tabular}

Notes: Columns 2-4 display the implied new car sales growth rate from equation (4) given the indicated parameter values, and $\beta=-0.32, \phi^{f}=0.248, \frac{Y_{p . c ., a}}{Y_{p . c .}}=0.66 ; \frac{Y_{p . c ., a}}{Y_{p . c .}}$ is the ratio of 1929 per capita income in states with farm population greater than the national average in 1930 to per capita income in all states (income data are from BEA table SA4 and population data are from Haines and ICPSR (2010)). Columns 5-7 show the fraction of actual new car sales growth explained. Actual new car sales growth in our sample period, 1929:Q2-Q3 to 1930:Q2-Q3, was -34 percent (NBER macrohistory series m01109).

percent decline in car sales accounted for by lower farm product prices for given assumptions about the redistribution factor and the aggregate multiplier. Columns (5) through (7) divide these estimates by the total decline in new car sales growth from 1929:Q2-Q3 to 1930:Q2-Q3 to show the fraction of the decline in new car sales growth explained by lower farm product prices. These estimates show that lower farm product prices had a significant effect on the downturn in the initial year of the Depression unless one believes: (1) that lower farm product prices were passed through to urban workers ( $\xi$ high), (2) that urban workers had a MPC similar to farmers $\left(\theta^{w}\right.$ close to $\left.\theta^{f}\right)$, and (3) that the aggregate multiplier was low. For example, a mid-range estimate of the redistribution factor (0.5) and of the aggregate multiplier (2) suggests that had farm product prices not fallen, the downturn in the initial year of the Depression would have been 15 percent smaller.

\section{Conclusion}

We argue that the agriculture sector played an important rule in propagating negative shocks that hit the U.S. economy in 1929 and 1930. Declines in world demand translated into large declines in farm product prices and farmers' incomes. Income declines in turn lowered farmers' expenditure, a process likely intensified by farmers' large nominal debt burdens.

We find that between mid-1929 and mid-1930 car sales fell most in states most exposed to farm product price declines. While less robust, we find a similar pattern across Ohio counties. The rough consistency of the county results with the state results is reassuring 
evidence that the effect we find is real and is not an artifact of a spurious cross-state correlation. These cross-sectional results are themselves of interest; they show, for instance, that knowing the farm share of a state's population in 1930 is quite predictive of the severity of a state's economic contraction in 1930. We are, however, ultimately interested in the aggregate implications of low farm product prices. To estimate these, we need a model. This section is necessarily more speculative. But a plausible range of parameters suggest that the mechanism through which farm product prices lowered spending by farmers explains 10-30 percent of the decline in U.S. output before the first banking crisis.

Importantly, this may be a conservative, lower bound for the impact of lower farm product prices on the U.S. economy. Because of the difficulty in quantifying the effect, our model deliberately excludes the contractionary effect of lower farm product prices operating through deflation and deflationary expectations. But this effect could have been large: plummeting farm product prices were one of the early indicators of the severe deflation that began in 1930.

This paper's concern is with a specific historical episode. But there are contemporary implications. A growing theoretical and empirical literature in macroeconomics shows the importance of redistribution as a propagation mechanism for macroeconomic shocks. Much of the empirical motivation for this literature comes from the experience of the 2008-2009 financial crisis and recession in which the costs of falling house prices were concentrated on indebted households. The large spending response of these households to this negative shock was a key driver of the recessions' severity (Mian et al., 2013).

Farmers in 1930 are the analog to mortgaged households in 2008. They had high levels of debt and their spending was sensitive to income declines. Just as declines in spending by mortgaged households explain a part of the 2008-09 recession, so declines in farmers' spending explain part of the early U.S. Great Depression. This result supports macroeconomists' recent focus on redistribution. It is also a reminder of the value of a detailed understanding of an economy's structure even for aggregate questions. Redistribution effects depend on the distribution of income and on the spending propensities of the affected groups. Thus our work also supports the long-standing concern of economic historians with agriculture in the interwar period. 


\section{References}

Alston, Lee J., "Farm Foreclosures in the United States During the Interwar Period," Journal of Economic History, 1983, 43 (4), 885-903.

Auclert, Adrien, "Monetary Policy and the Redistribution Channel," American Economic Review, 2019, 109 (6), 2333-2367.

Board of Governors of the Federal Reserve System, Banking and Monetary Statistics, 191419411943.

Bordo, Michael David, "The Effects of Monetary Change on Relative Commodity Prices and the Role of Long-Term Contracts," Journal of Political Economy, 1980, 88, 1088-1109.

Broer, Tobias, Niels-Jakob Harbo Hansen, Per Krusell, and Erik Öberg, "The New Keynesian Transmission Mechanism: A Heterogenous-Agent Perspective," Review of Economic Studies, 2020, 87 (1), 77-101.

Cairnes, John E., Essays in Political Economy: Theoretical and Applied, Macmillan and Co., 1873.

Clark, Evans, The Internal Debts of the United States, The Macmillan Company, 1933.

Cloyne, James, Clodomiro Ferreira, and Paolo Surico, "Monetary Policy when Households have Debt: New Evidence on the Transmission Mechanism," Review of Economic Studies, 2020, 87 (1), 102-129.

Cooper, Russell W. and John C. Haltiwanger, "Automobiles and the National Industrial Recovery Act: Evidence on Industry Complementarities," Quarterly Journal of Economics, 1993, 108 (4), 1043-1071.

Ezekiel, Mordecai and Louis H. Bean, Economic Bases for the Agricultural Adjustment Act, Government Printing Office, 1933.

Federico, Giovanni, "Not Guilty? Agriculture in the 1920s and the Great Depression," Journal of Economic History, 2005, 65 (4), 949-976.

Fisher, Irving, Booms and Depressions, Adelphi, 1932.

Friedman, Milton and Anna Jacobson Schwartz, A Monetary History of the United States, 1867-1960, Princeton University Press, 1963.

Garrett, Thomas A. and David C. Wheelock, "Why did Income Growth vary across States during the Great Depression?," Journal of Economic History, 2006, 66 (2), 456-466.

Gelman, Michael, Yuriy Gorodnichenko, Shachar Kariv, Dmitri Koustas, Matthew Shapiro, Dan Silverman, and Steven Tadelis, "The Response of Consumer Spending to Changes in Gasoline Prices," 2019. Working Paper.

Gorton, Gary, Toomas Laarits, and Tyler Muir, "1930: First Modern Crisis," 2019. NBER Working Paper 25452.

Haines, Michael and ICPSR, "Historical, Demographic, Economic, and Social Data: The United States, 1790-2002," ICPSR Study 02896-v3 2010. Ann Arbor, MI: Inter-university Consortium for Political and Social Research [Distributer].

_ , Price Fishback, and Paul Rhode, "United States Agricultural Data, 1840-2010," ICPSR Study 35206-v2 2015. Ann Arbor, MI: Inter-university Consortium for Political and Social Research [Distributer]. 
Hamilton, James D., "Was the Deflation During the Great Depression Anticipated? Evidence from the Commodity Futures Market," American Economic Review, 1992, pp. 157-178.

Hausman, Joshua K., Paul W. Rhode, and Johannes F. Wieland, "Recovery from the Great Depression: The Farm Channel in Spring 1933," American Economic Review, 2019, 109 (2), 427-472.

Kaplan, Greg, Benjamin Moll, and Giovanni L. Violante, "Monetary Policy According to HANK," American Economic Review, 2018, 108 (3), 697-743.

Kindleberger, Charles P., The World in Depression, 1929-1939, University of California Press, 1973.

Krueger, D., K. Mitman, and F. Perri, "Macroeconomics and Heterogeneity, including Inequality," Handbook of Macroeconomics, 2016. Chapter 11.

Madsen, Jakob B., "Agricultural Crises and the International Transmission of the Great Depression," Journal of Economic History, 2001, 61 (2), 327-365.

McKay, Alisdair, Emi Nakamura, and Jón Steinsson, "The Power of Forward Guidance Revisited," American Economic Review, 2016, 106 (10), 3133-3158.

Mian, Atif, Kamalesh Rao, and Amir Sufi, "Household Balance Sheets, Consumption, and the Economic Slump," Quarterly Journal of Economics, 2013, 128 (4), 1687-1726.

Olney, Martha L., "Avoiding Default: The Role of Credit in the Consumption Collapse of 1930," Quarterly Journal of Economics, 1999, 114 (1), 319-335.

Patterson, Christina, "The Matching Multiplier and the Amplification of Recessions," 2019. Working Paper.

Romer, Christina D., "The Prewar Business Cycle Reconsidered: New Estimates of Gross National Product, 1869-1908," Journal of Political Economy, 1989, 97 (1), 1-37.

_ , "The Great Crash and the Onset of the Great Depression," Quarterly Journal of Economics, 1990, 105 (3), 597-624.

Romer, Christina D, "The nation in depression," Journal of Economic Perspectives, 1993, 7 (2), 19-39.

Rosenbloom, Joshua L. and William A Sundstrom, "The Sources of Regional Variation in the Severity of the Great Depression: Evidence from U.S. Manufacturing, 1919-1937," Journal of Economic History, 1999, 59 (3), 714-747.

Snowden, Kenneth A., "Debt on Nonfarm Structures, by Type of Debt, Property, and Holder: 1896-1952," in Susan B. Carter, Scott Sigmund Gartner, Michael R. Haines, Alan L. Olmstead, Richard Sutch, and Gavin Wright., eds., Historical Statistics of the United States, Earliest Times to the Present: Millennial Edition, Cambridge University Press, 2006. Table Dc903-928, series Dc906.

Strauss, Frederick and Louis Hyman Bean, Gross Farm Income and Indices of Farm Production and Prices in the United States, 1869-1937 number 703, United States Department of Agriculture, 1940.

Temin, Peter, Did Monetary Forces Cause the Great Depression?, W. W. Norton \& Company, 1976.

United States Department of Agriculture, Yearbook of Agriculture, Government Printing 
Office, 1931.

_ , Yearbook of Agriculture, Government Printing Office, 1932.

_ , Yearbook of Agriculture, Government Printing Office, 1933.

_ , Yearbook of Agriculture, Government Printing Office, 1934.

_ , Agricultural Statistics, Government Printing Office, 1936.

_ , "Income Parity for Agriculture: Part II - Expenses for Agricultural Production," 1940. Section 3. Purchases, Depreciation, and Value of Farm Automobiles, Motortrucks, Tractors, and other Farm Machinery.

_, Price Spreads Between Farmers and Consumers for Food Products 1913-44 1945. From the Bureau of Agricultural Economics, Miscellaneous Publication number 576.

United States Department of Labor, "Retail Prices," Monthly Labor Review, 1936, 43 (1), 219-244.

_, Retail Prices of Food, 1923-36, Government Printing Office, 1938. Bulletin, number 635.

United States Department of Treasury, Bureau of Internal Revenue, An Analysis of the Effects of the Processing Taxes Levied Under the Agricultural Adjustment Act, Government Printing Office, 1937. Prepared by the Bureau of Agricultural Economics in the United States Department of Agriculture.

U.S. Department of Commerce, "Index of Sales of General Merchandise in Small Towns and Rural Areas," Survey of Current Business, December 1934, 14 (12), 20.

_ , "Index of Sales of New Passenger Automobiles," Survey of Current Business, April 1934, $14(4), 16-19$.

_, "Index of Variety Store Sales," Survey of Current Business, March 1934, 14 (3), 17-20.

_ , Historical Statistics of the United States, Government Printing Office, 1975.

Wallis, John Joseph, "Employment in the Great Depression: New Data and Hypotheses," Explorations in Economic History, 1989, 26, 45-72.

Warren, George F. and Frank A. Pearson, Gold and Prices, John Wiley \& Sons, 1935.

Werning, Iván, "Managing a Liquidity Trap: Monetary and Fiscal Policy," NBER Working Paper 173442011.

Wickens, David L., "Farm-Mortgage Credit," 1932. United States Department of Agriculture, Technical Bulletin No. 288. 


\section{A Data appendix for Table 1}

A.1 Prices Price data come from United States Department of Agriculture (1936) with the exception of tobacco price data which come from Strauss and Bean (1940), table 24, p. 69. We seasonally adjust these data by regressing the log price on monthly dummies, excluding the year 1933 because of the extreme price movements in spring 1933. For further details on the price sources, see Hausman et al. (2019), online appendix C.1. All sources and methods used for the prices in Table 1 are the same as those described there.

\section{A.2 Production}

- For wheat, corn, oats, cotton, tobacco, hay, potatoes, milk and chickens, farm product value, production, and trade data are from United States Department of Agriculture (1934) and United States Department of Agriculture (1936) as specified in appendix C.1 of Hausman et al. (2019).

- Cattle: 1929 farm product value is equal to that given for cattle and calves in United States Department of Agriculture (1931), table 371, p. 842 minus 1929 calf production times the 1929 calf producer price from United States Department of Agriculture (1936) table 307, p. 213. Production in 1929 is from United States Department of Agriculture (1931), table 370, pp. 840-841. Production in 1930 is from United States Department of Agriculture (1932), table 328, pp. 782-783. Trade data are for beef and beef products and are from United States Department of Agriculture (1933), table 320, p. 600.

- Hogs: Farm product value is from United States Department of Agriculture (1931), table 396, p. 860. Production in 1929 is from United States Department of Agriculture (1931), table 395, p. 859; production in 1930 is from United States Department of Agriculture (1932), table 347, p. 795. Trade data are for hog products and are from United States Department of Agriculture (1933), table 341, p. 792.

- Eggs: Sources are as specified in Hausman et al. (2019), except trade data which are from United States Department of Agriculture (1932), table 438, p. 859.

\section{B Data appendix for Figure 3}

The nominal price index for traded crops is equal to $\sum_{j}$ price $_{j} \times w_{e} i g h t_{j}$ for traded crops $j$, and the nominal price index for nontraded farm products is equal to $\sum_{k}$ price $_{k} \times w_{e} i g h t_{k}$ for nontraded farm products $k$. The indices shown in the figure are put in real terms by dividing by the nonseasonally adjusted CPI, FRED series CPIAUCNS (the CPI does not have obvious seasonality at this time).

For the prices of all products other than wool, the sources and method of seasonal adjustment are as detailed above (appendix A.1 with further details in Hausman et al. (2019), online appendix C.1). For wool, monthly prices are from United States Department of Agriculture (1936), table 347, p. 244, with seasonal adjustment done using data from January 1926 through December 1935, excluding 1933. 


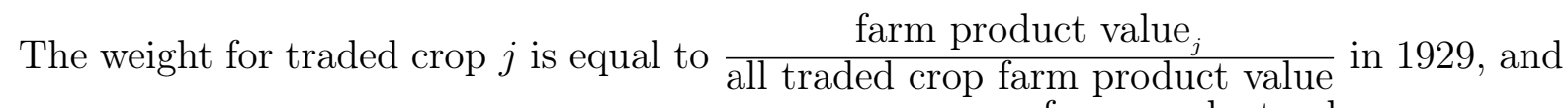
the weight for nontraded farm product $k$ is equal to $\frac{\text { farm product value }}{\text { all nontraded farm product value }_{\text {in }}}$ 1929. For milk and chickens we use the value sold rather than produced. Farm product value for cattle and hogs are as listed above (appendix A.2). All other farm product value data come from Haines et al. (2015).

\section{New registrations as a measure of car sales}

In the paper, we use new car registrations as a measure of new car sales. The U.S. Department of Commerce (1934b) provides a useful discussion and data on the relationship between new registrations and unit sales. The Department of Commerce writes (pp. 16-17):

Registration figures have been available and in normal times they undoubtedly offer a rather accurate picture of the general trend in unit sales.

. . . [Sales] represent the number of cars actually sold each month, whereas the registration figures are unduly decreased or increased in certain months because of lax enforcement of licensing provisions and other factors, which allow the holding over of car sold in one month for registration in a later month when the cost of licensing will be lower. The months of June and July and December and January are especially affected by these factors.

While this statement raises concerns about measurement error from using new registrations as an indicator of sales, the available data suggest this error is quite small. The Department of Commerce (U.S. Department of Commerce, 1934b) computed an index of the dollar volume of nationwide new car sales. The index begins in 1929, but actual (rather than imputed) data on unit sales begin only in 1930. Since the data are also unavailable by state, the series is of no use for our paper. Still, we can use it to see how well new car registrations approximate dollar sales during the Depression. Reassuringly, the answer is very well. Over the entire period 1930-33 and in 1930 alone, the correlation between month-over-month percentages in dollar sales and new registrations is roughly $0.88 .{ }^{27}$ Figure C.1 confirms the close correspondence between the two series.

\footnotetext{
${ }^{27}$ Nationwide new passenger car registrations are from NBER macrohistory series m01109.
} 
Figure C.1 - Dollar volume of car sales and new registrations

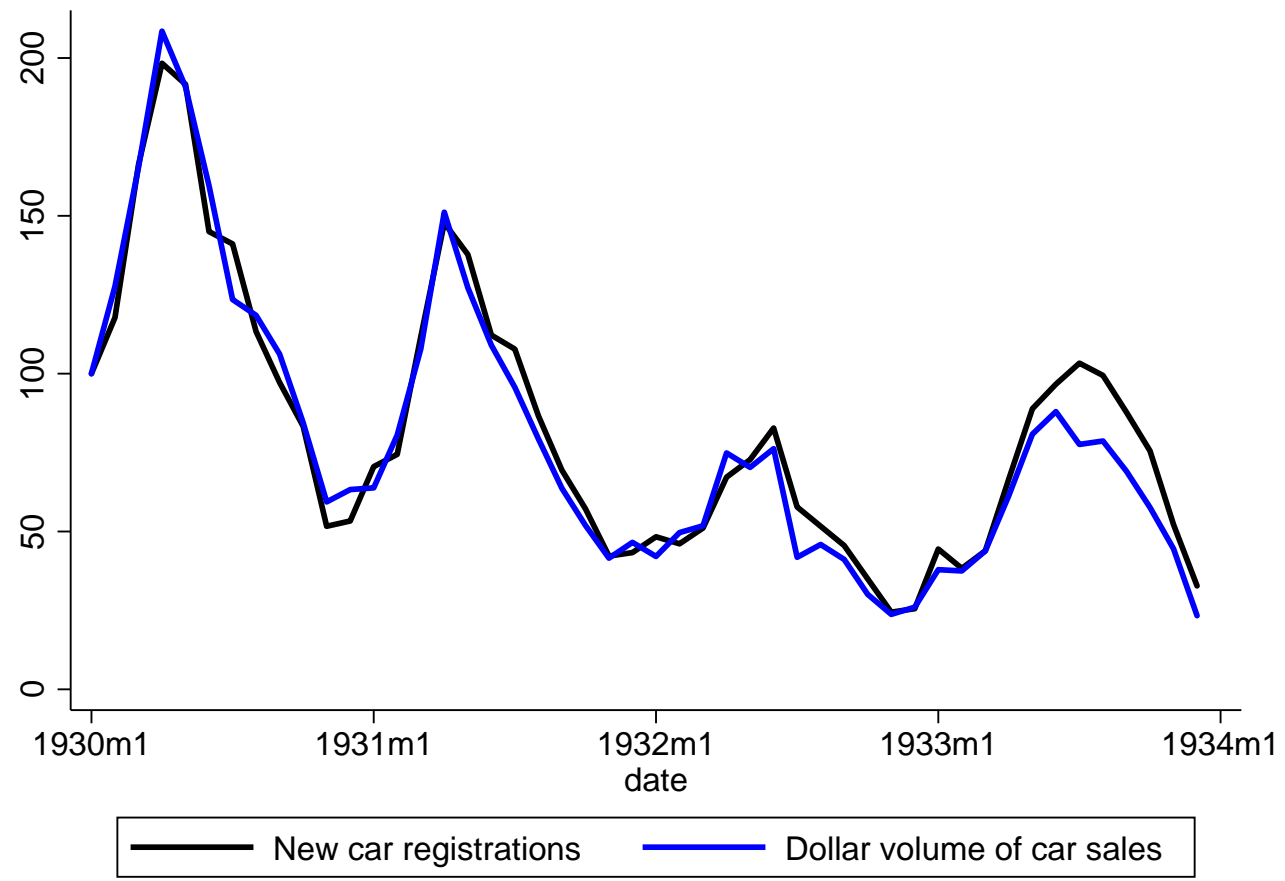

Note: Both series are not seasonally adjusted and are indexed to 100 in January 1930. Sources: New car registrations, NBER macrohistory series m01109; dollar volume of sales index, U.S. Department of Commerce (1934b).

\section{Car sales by farm share quartile excluding AL and MS}


Figure D.1 - Car sales by farm share quartile excluding AL and MS

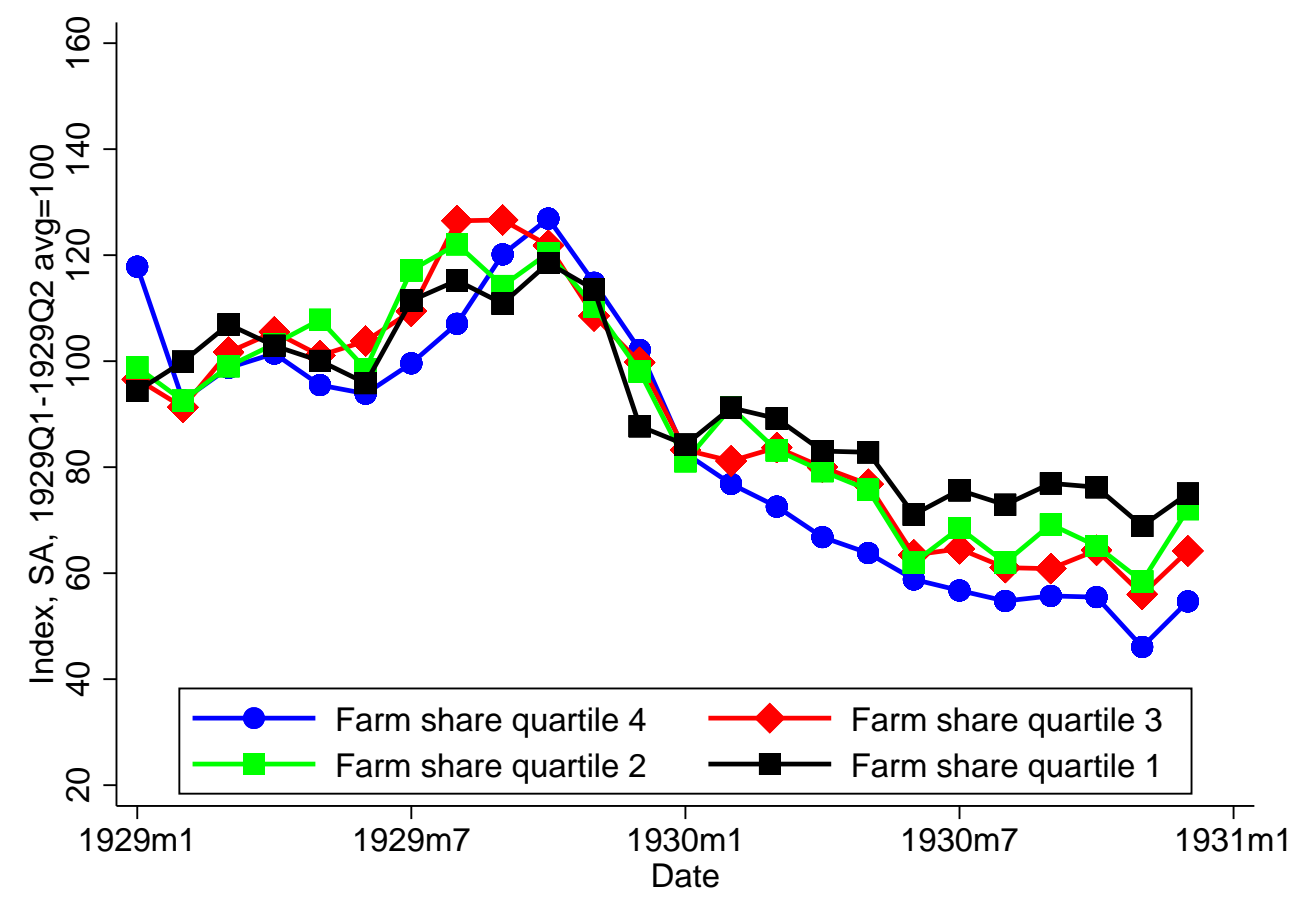

Sources: Car sales - see text; farm share of the population - Haines and ICPSR (2010).

\section{E County car sales data source}

We compile the data on car sales in Ohio as follows.

Car sales in Jan. 1929: Bulletin of Business Research, 2/1929, table II, p. 6. Car sales in Feb. 1929: Bulletin of Business Research, 3/1929, table II, p. 6. Car sales in Mar. 1929: Bulletin of Business Research, 4/1929, table II, p. 6. Car sales in Apr. 1929: Bulletin of Business Research, 5/1929, table II, p. 6. Car sales in May 1929: Bulletin of Business Research, 6/1929, table II, p. 7. Car sales in Jun. 1929: Bulletin of Business Research, 7/1929, table II, p. 6. Car sales in Jul. 1929: Bulletin of Business Research, 8/1929, table II, p. 6. Car sales in Aug. 1929: Bulletin of Business Research, 9/1929, table II, p. 6. Car sales in Sep. 1929: Bulletin of Business Research, 10/1929, table II, p. 6. Car sales in Oct. 1929: Bulletin of Business Research, 11/1929, table II, p. 6. Car sales in Nov. 1929: Bulletin of Business Research, 12/1929, table II, p. 6. Car sales in Jan. 1930: Bulletin of Business Research, 2/1930, table II, p. 6. Car sales in Feb. 1930: Bulletin of Business Research, 3/1930, table II, p. 6. Car sales in Mar. 1930: Bulletin of Business Research, 4/1930, table II, p. 6. Car sales in Apr. 1930: Bulletin of Business Research, 5/1930, table II, p. 6. Car sales in May 1930: Bulletin of Business Research, 6/1930, table II, p. 7. Car sales in Jun. 1930: Bulletin of Business Research, 7/1930, table II, p. 6. Car sales in Jul. 1930: Bulletin of Business Research, 8/1930, table II, p. 6. Car sales in Aug. 1930: Bulletin of Business Research, 9/1930, table II, p. 6. Car sales in Sep. 1930: Bulletin of Business Research, 10/1930, table III, p. 6. 
Car sales in Oct. 1930: Bulletin of Business Research, 11/1930, table II, p. 7.

Car sales in Nov. 1930: Bulletin of Business Research, 12/1930, table II, p. 6.

Exceptions:

- Belmont county, Jul. 1929: No value is given for Belmont county in the 8/1929 Bulletin of Business Research. We infer the number of cars using: The number of cars in Belmont county in Aug. 1929 as given in Bulletin of Business Research 9/1929, table II p. 6, which equals 266, and the percent change in the number of cars in Belmont county from Jul. 1929 to Aug. 1929 as given in the Bulletin of Business Research 9/1929, table II p. 6 which equals 4 percent.

- Belmont county, Feb. 1930: No value is given for Belmont county in the 3/1930 Bulletin of Business Research. We infer the number of cars using: The number of cars in Belmont county in Mar. 1930 as given in the Bulletin of Business Research 4/1930, table II p. 6, which equals 147, and the percent change in the number of cars in Belmont county from Feb. 1930 to Mar. 1930 as given in the Bulletin of Business Research 4/1930, table II p. 6 which equals -7 percent.

- Defiance, Sep. 1929: No value is given for Defiance county in the 10/1929 Bulletin of Business Research. We infer the number of cars using: The number of cars in Defiance county in Oct. 1929 as given in theBulletin of Business Research 11/1929, table II p. 6, which equals 69 and the percent change in the number of cars in Defiance county from Sep. 1929 to Oct. 1929 as given in the Bulletin of Business Research 11/1929, table II p. 6 which equals -27 percent.

\section{F Appendix tables}


Table F.1 - Cross-state regressions, population weighted

\begin{tabular}{|c|c|c|c|c|c|c|}
\hline & $(1)$ & $(2)$ & $(3)$ & $(4)$ & $(5)$ & $(6)$ \\
\hline Right hand side variables: & & & & & & \\
\hline \% pop. on farms 1930 & $\begin{array}{c}-0.31^{* * *} \\
(0.083)\end{array}$ & $\begin{array}{r}-0.23^{* *} \\
(0.094)\end{array}$ & $\begin{array}{c}-0.30^{* *} \\
(0.11)\end{array}$ & & & \\
\hline Crops sold p.c. 1929 (\$s) & & & & $\begin{array}{c}-0.14^{* * *} \\
(0.051)\end{array}$ & $\begin{array}{r}-0.061 \\
(0.037)\end{array}$ & $\begin{array}{r}-0.078 \\
(0.049)\end{array}$ \\
\hline Population 1930 (millions) & & $\begin{array}{c}-0.079 \\
(0.39)\end{array}$ & $\begin{array}{c}-0.26 \\
(0.43)\end{array}$ & & $\begin{array}{c}0.12 \\
(0.35)\end{array}$ & $\begin{array}{c}0.050 \\
(0.37)\end{array}$ \\
\hline 1928 car sales p.c. $(1000$ s) & & $\begin{array}{r}-0.39^{*} \\
(0.22)\end{array}$ & $\begin{array}{c}-0.53^{* *} \\
(0.25)\end{array}$ & & $\begin{array}{c}-0.23 \\
(0.25)\end{array}$ & $\begin{array}{r}-0.27 \\
(0.26)\end{array}$ \\
\hline 1930 drought & & & $\begin{array}{r}-3.18 \\
(2.86)\end{array}$ & & & $\begin{array}{r}-1.68 \\
(2.99)\end{array}$ \\
\hline 1929 drought & & & $\begin{array}{c}0.42 \\
(5.28)\end{array}$ & & & $\begin{array}{c}0.51 \\
(5.75)\end{array}$ \\
\hline Region Fixed Effects & No & Yes & Yes & $\mathrm{No}$ & Yes & Yes \\
\hline$R^{2}$ & 0.33 & 0.59 & 0.61 & 0.20 & 0.57 & 0.57 \\
\hline Observations & 49 & 49 & 49 & 49 & 49 & 49 \\
\hline
\end{tabular}

Notes: The dependent variable is the percent change in non-seasonally adjusted car sales from the 1929:Q2Q3 average to the 1930:Q2-Q3 average. p.c. means per capita. Robust standard errors in parenthesis. ${ }^{*} p<0.1,{ }^{* *} p<0.05,{ }^{* * *} p<0.01$ Sources: New car sales - see text; population and percent of the population on farms - the 1930 Census as reported in Haines and ICPSR (2010); 1929 value of crops sold per capita - the 1940 Census as reported in Haines et al. (2015); 1928 car sales - Automotive Industries, 2/23/29, p. 271; drought dummies - National Climate Data Center. Region fixed effects are dummy variables for the four census regions - northeast, midwest, south, and west. 
Table F.2 - Cross-county regressions, population weighted

\begin{tabular}{|c|c|c|c|c|c|c|}
\hline & (1) & $(2)$ & $(3)$ & $(4)$ & $(5)$ & $(6)$ \\
\hline Farm share $1930(\%)$ & $\begin{array}{c}-0.17 \\
(0.10)\end{array}$ & & $\begin{array}{c}0.056 \\
(0.083)\end{array}$ & & & \\
\hline Crop value sold p.c. $1929(\$)$ & & $\begin{array}{r}-0.22^{* *} \\
(0.085)\end{array}$ & & $\begin{array}{c}0.0054 \\
(0.069)\end{array}$ & & \\
\hline Cotton, tobacco, cereals, wool p.c. 1929 & & & & & $\begin{array}{c}-0.26^{* *} \\
(0.12)\end{array}$ & $\begin{array}{r}-0.19^{*} \\
(0.11)\end{array}$ \\
\hline Nontraded farm p.c. 1929 & & & & & $\begin{array}{c}0.0044 \\
(0.040)\end{array}$ & $4 \begin{array}{c}0.059^{*} \\
(0.034)\end{array}$ \\
\hline Population 1930 (millions) & & & $\begin{array}{c}12.4^{* * *} \\
(2.29)\end{array}$ & $\begin{array}{c}11.3^{* * *} \\
(1.94)\end{array}$ & & $\begin{array}{l}12.5^{* * *} \\
(2.10)\end{array}$ \\
\hline 1928 car sales p.c. (1000s) & & & $\begin{array}{c}-0.62^{* * *} \\
(0.18)\end{array}$ & $\begin{array}{c}-0.63^{* * *} \\
(0.19)\end{array}$ & & $\begin{array}{c}-0.60^{* * *} \\
(0.19)\end{array}$ \\
\hline$R^{2}$ & 0.09 & 0.15 & 0.54 & 0.53 & 0.15 & 0.55 \\
\hline Observations & 49 & 49 & 49 & 49 & 49 & 49 \\
\hline
\end{tabular}

Notes: The dependent variable is the percent change in non-seasonally adjusted auto sales from the 1929:Q2Q3 average to the 1930:Q2-Q3 average. p.c. means per capita. While we observe monthly auto sales in 1929-30 in 50 counties, there are only 49 observations since 1928 car sales were not reported for Morgan county. Robust standard errors in parenthesis. ${ }^{*} p<0.1,{ }^{* *} p<0.05,{ }^{* * *} p<0.01$ Sources: New car registrations - see text; population and percent of the population on farms - the 1930 Census as reported in Haines and ICPSR (2010); 1929 value of crops sold per capita and farm product categories - the 1940 Census as reported in Haines et al. (2015); 1928 car sales - calculated from the Industrial and Commercial Ohio Yearbook (1930), table XVI, p. 104 which lists by county both 1929 car sales and the 1928-29 percent change in car sales. 